Article

\title{
Prediction of Post-Yield Strain from Loading and Unloading Phases of Pressuremeter, Triaxial, and Consolidation Test Curves for Sustainable Embankment Design
}

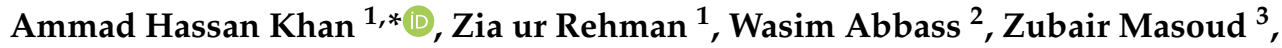 \\ Abdeliazim Mustafa Mohamed ${ }^{4}$ D, Dina Mohamed Fathi ${ }^{5}$, Mubashir Aziz ${ }^{6,7}$ iD and Safeer Abbas ${ }^{2}$
}

check for updates

Citation: Khan, A.H.; Rehman, Z.u.; Abbass, W.; Masoud, Z.; Mohamed, A.M.; Fathi, D.M.; Aziz, M.; Abbas, S. Prediction of Post-Yield Strain from Loading and Unloading Phases of Pressuremeter, Triaxial, and Consolidation Test Curves for Sustainable Embankment Design. Sustainability 2022, 14, 2535. https:// doi.org/10.3390/su14052535

Academic Editor: Jongmuk Won

Received: 25 January 2022

Accepted: 18 February 2022

Published: 22 February 2022

Publisher's Note: MDPI stays neutral with regard to jurisdictional claims in published maps and institutional affiliations.

Copyright: (C) 2022 by the authors. Licensee MDPI, Basel, Switzerland. This article is an open access article distributed under the terms and conditions of the Creative Commons Attribution (CC BY) license (https:// creativecommons.org/licenses/by/ $4.0 /)$.
1 Department of Transportation Engineering and Management, University of Engineering and Technology, Lahore 54890, Pakistan; gzia718@uet.edu.pk

2 Department of Civil Engineering, University of Engineering and Technology Lahore, Lahore 54890, Pakistan; wabbass@uet.edu.pk (W.A.); safeer.abbas@uet.edu.pk (S.A.)

3 Independent Researcher, Lahore 54810, Pakistan; 978.xyz@gmail.com

4 Department of Civil Engineering, Prince Sattam Bin Abdulaziz University, Alkharj 16273, Saudi Arabia; a.bilal@psau.edu.sa

5 Department of Structure Engineering and Construction Management, Future University, Cairo 11835, Egypt; dina.mohamed@fue.edu.eg

6 Department of Civil and Environmental Engineering, King Fahd University of Petroleum and Minerals, Dhahran 31261, Saudi Arabia; mubashir.aziz@kfupm.edu.sa

7 Interdisciplinary Research Center for Construction and Building Materials, King Fahd University of Petroleum and Minerals, Dhahran 31261, Saudi Arabia

* Correspondence: chair-tem@uet.edu.pk

\begin{abstract}
Exponential development of post-yield strain $\left(\varepsilon_{\text {post }}\right)$ is a pivotal indicator of failure in embankments constructed on soft saturated clays. This paper characterizes saturated clay stratum comprising very soft to very stiff stratigraphy, with plasticity index (PI) ranging from $19 \%$ to $31 \%$, by performing widely used geotechnical engineering tests, i.e., the prebored pressuremeter (PMT) test, the triaxial (TXL) test, and constant-rate-of-strain (CRS) consolidation. PMT, TXL, and CRS tests were performed at a strain rate range of $0.18 \% / \mathrm{min}$ to $0.21 \% / \mathrm{min}$ to explore the yield stress $\left(\sigma_{y}^{\prime}\right)$, the pre-yield strain $\left(\varepsilon_{\text {pre }}\right)$, and the post-yield strain $\left(\varepsilon_{\text {post }}\right)$. Results indicate that $\varepsilon_{\text {post }} / \varepsilon_{\text {pre }}$ for PMT, TXL, and CRS stress-strain curves range from 2.7 to 19 in the loading phase and 2 to 21 in the unloading phase. An exponential increase in $\varepsilon_{\text {post }} / \varepsilon_{\text {pre }}$ is observed in the range of 10 to 21 for very soft to soft clay which is congruent with the realistic sustainable range of 4 to 30 for embankment

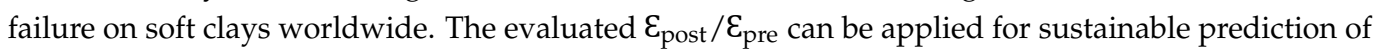
post-failure evolution of strains in embankments on soft clays. Simplistic correlations are developed for approximation and prediction of $\varepsilon_{\text {post }}$ as a function of $\sigma_{y}^{\prime}, \varepsilon_{\text {pre }}$ and maximum applied pressure $\left(\mathrm{P}_{\max }\right)$ for loading and unloading phases with reasonable accuracy. The intuitive zone of critical $\varepsilon_{\text {post }}$ is quantified for impending failure in embankments for maximum applied pressure $\left(\mathrm{P}_{\max }\right)$, ranging from $36 \mathrm{kPa}$ to $100 \mathrm{kPa}$ for very soft to soft clay for use in sustainable embankment design and construction. Variation in predicted versus measured results of an individual site is observed to be within $\pm 10 \%$ of line of equality.
\end{abstract}

Keywords: geotechnical engineering; clay; sustainability; embankments; strain; stress; pressuremeter; triaxial; consolidation

\section{Introduction}

The need to build the road embankments (usually 3 to $4 \mathrm{~m}$ high) on soft clay strata is observed worldwide; however, a number of embankments fail each year due to the development of exponential post-yield strain, which is the key parameter for slope design [1-3]. Post-construction settlements are very serious for the performance of road embankments [4]. 
Embankments fail mainly due to the onset of yielding in soft clay when the effective stress state moves from an overconsolidated condition to a normally consolidated condition, and the behaviour of clay moves from the partially drained phase to the undrained phase [5-7]. As mentioned for soft clays at Rio and Muar-F embankments, the prediction of large strain residual undrained shear strength is based on yield stress. The yielding is considered as a fundamental feature of lightly overconsolidated saturated clays, resulting in exponential post-yield strains [8-11]. The yield stress (herein denoted as $\sigma_{\mathrm{y}}^{\prime}$ ) acts as the separating point for the elastic (pre-yield) and plastic (post-yield) response of clays [11-13]. This describes the pre-failure (crest settlement) and post-failure (large displacement in the toe of an embankment slope) as significant stages of slope movement. Yielding of soft clays has been studied extensively in the past to understand the stress-strain behavior during failure of embankments [14-16].

A study on embankment failures provides the basis for an assessment of the performance of infrastructure built on soft saturated clays [17]. The prediction of embankment settlement is significant for stability [18]. Consolidation behavior of soft clay under embankment is critical [19]. The soft sub-soils under the embankments are critical for stability [20-23]. Due to excavation in soft clays, the lateral displacement of embankment's toe is significant to practicing engineers [24-30]. The development of strains causing settlement at the crest of embankment shows the initial sign of failure. Stress levels (due to height of embankment) which exceed the yield stress in stiff soils generate low excess pore pressures, whereas soft clays are prone to the development of high pore pressure, ultimately causing the onset of yielding and large post-yield strains [31].

An increase in the height of the embankment causes an increase in vertical stress, resulting in the yielding of clay and the enhancement of the horizontal deformation at the toe, which is sensitive to moisture content. Hence, the failure of embankment constructed on soft saturated soils is closely related to the embankment height; hence, the maximum pressure exerted due to height of the embankment is mainly related to the large post-yield strains which causes the embankment to fail. The strain-softening behavior in clay arises due to building up of excess pore-water pressure due to strains developed in saturated clay strata. The detailed parameters of these failure cases show that the post-failure deformation was very large as compared with pre-failure deformation as presented in Table 1 for embankment failure cases worldwide.

Table 1. Past studies on pre-failure and post-failure deformation during embankment failures.

\begin{tabular}{|c|c|c|c|c|c|c|}
\hline & Name & Soil Type & $\begin{array}{l}\text { Pre-Failure } \\
\text { Lateral Def. } \\
\text { at Toe }(\mathrm{mm})\end{array}$ & $\begin{array}{l}\text { Post-Failure } \\
\text { Lateral Def. } \\
(\mathrm{mm})\end{array}$ & $\begin{array}{l}\text { Ratio of Post } \\
\text { to Pre-Failure } \\
\text { Deformation }\end{array}$ & Reference \\
\hline 1 & $\begin{array}{c}\text { Rio de Janiero, } \\
\text { Brazil }\end{array}$ & Very soft clay & 155 & 700 & 4.5 & Costa-Filho (1977) [32] \\
\hline 2 & Thames, UK & $\begin{array}{l}\text { Soft to very soft } \\
\text { clay }\end{array}$ & 450 & 2200 & 4.9 & $\begin{array}{l}\text { Marsland and Powell } \\
\text { (1977) [5] }\end{array}$ \\
\hline 3 & Cubzac-A, France & $\begin{array}{l}\text { Soft to very soft } \\
\text { cay }\end{array}$ & 130 & 1400 & 10.7 & $\begin{array}{c}\text { Magnan, Humbert, and } \\
\text { Mouratidis (1982), [33] } \\
\text { Blondeau et al. (1977) } \\
\text { [34] }\end{array}$ \\
\hline 4 & Kalix, Sweden & $\begin{array}{l}\text { Soft to very soft } \\
\text { clay }\end{array}$ & $>105$ & 700 & $<6.7$ & $\begin{array}{l}\text { Holtz and Holm (1979) } \\
\text { [35] }\end{array}$ \\
\hline 5 & Kings Lynn, UK & Soft clay & $>125$ & 1500 & $<12$ & $\begin{array}{l}\text { Wilkes (1972), [36] Wroth } \\
\text { and Simpson (1972) [37] }\end{array}$ \\
\hline 6 & $\begin{array}{c}\text { St. Alban-A, } \\
\text { Quebec, Canada }\end{array}$ & $\begin{array}{l}\text { Soft to very soft } \\
\text { clay }\end{array}$ & $>40$ & 1200 & $<30$ & $\begin{array}{l}\text { La Rochelle et al. (1974) } \\
\text { [38] }\end{array}$ \\
\hline 7 & Muar-F, Malaysia & $\begin{array}{c}\text { Soft to very soft } \\
\text { clay }\end{array}$ & 370 & 1500 & 4.1 & Poulos et al. (1990) [39] \\
\hline
\end{tabular}


Large vertical stress due to overburden load acts in embankment in the initial stage of failure which gradually transforms to the large horizontal stress acting at the toe resulting in generation of the large horizontal failure strain. Figure 1 shows the embankment failure due to excavation, where the effective major principal stress $\left(\sigma^{\prime}{ }_{1}\right)$ and effective minor principal stresses $\left(\sigma_{3}^{\prime}\right)$ are shown at points $A, B$, and $C$. The axes of $\sigma_{1}^{\prime}$ and $\sigma_{3}^{\prime}$ are rotated through $45^{\circ}$ at stage $\mathrm{B}$ and $90^{\circ}$ at stage $\mathrm{C}$. The principal stress axis rotation, in case of embankments on soft soils, is well described [40]. The stage C (last stage of the failure of embankment at the toe) simulates the stresses acting in pressuremeter testing, whereas the stress condition at stage A is simulated by the TXL and CRS tests (where the sample is compressed vertically up to failure), as shown in Figure 1.

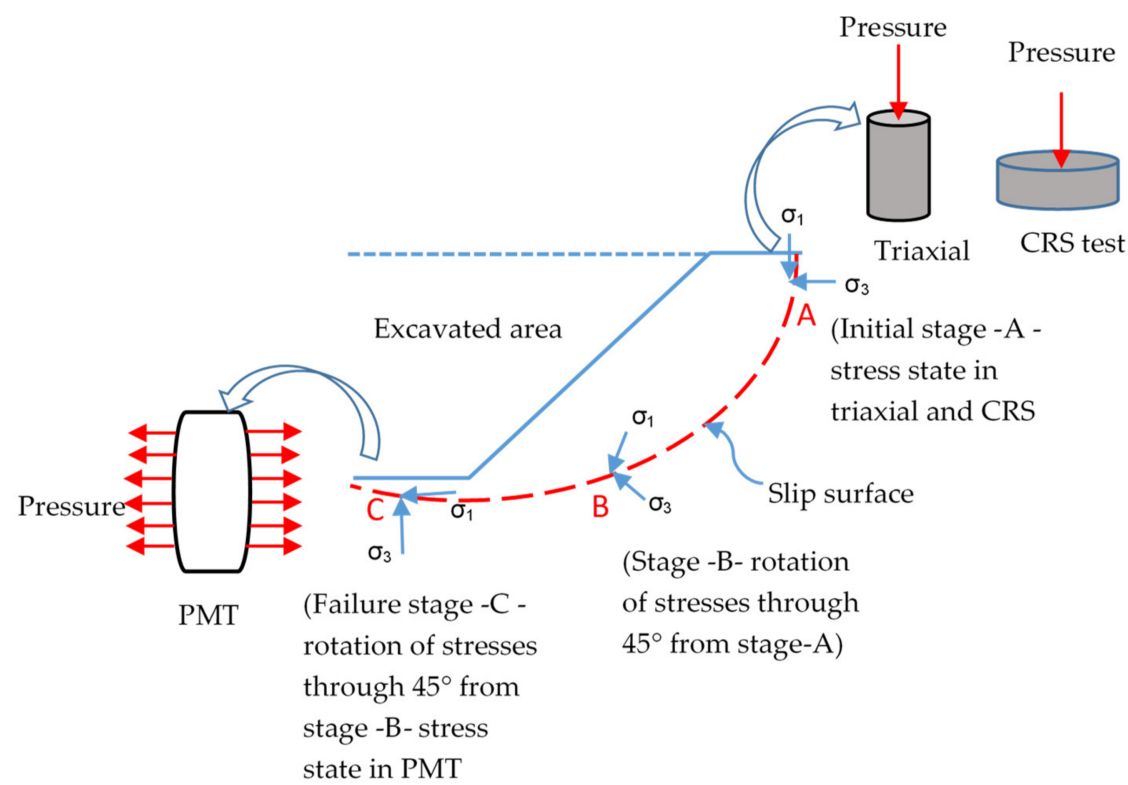

(a)

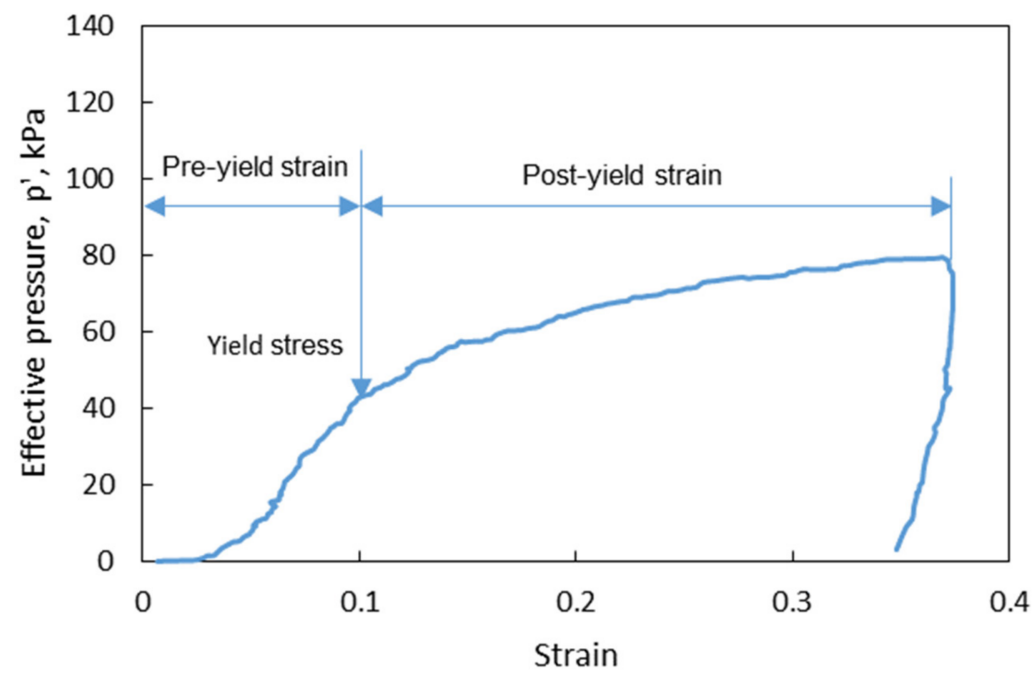

(b)

Figure 1. (a) Rotation of principle stress axis during embankment failure (Initial Stage " $A$ ", Intermediate Stage "B" and Failure Stage "C") (b) Pre-yield strain, post-yield strain, and yield stress shown in the pre-bored pressuremeter curve.

The in situ soil testing tool-like pressuremeter (PMT) can be used to obtain the stressstrain relation of saturated clay from which the pre-yield and post-yield strains can be evaluated. According to [41,42], the pressuremeter (PMT) test can be used effectively for 
the study of horizontal strains in clays by stressing the soil in lateral direction. The PMT test is significant as it simulates the embankment failure at the toe where the direction of applied stress and the corresponding strain is horizontal, as shown in Figure 1. As the large deformation occurs in the case of embankment failure, the in situ prebored pressuremeter (PMT) test, hence, is an ideal tool compared to laboratory tests, including TXL and CRS tests. The pressuremeter test can be used as reference to the other tests for stress-strain analysis $[43,44]$.

The prediction of short- and long-term tunnelling-induced ground movements was presented by [45] in London Clay, based on the stiffness of intact samples evaluated by oedometer and triaxial tests. Tavenas [6] predicted the large lateral deformation at the toe of embankment from settlement at the centre of the embankment. In light of previous studies, the yield stress $\left(\sigma_{\mathrm{y}}^{\prime}\right)$, the pre-yield strain $\left(\varepsilon_{\text {pre }}\right)$, and the post-yield strain $\left(\varepsilon_{\text {post }}\right)$, based on pressuremeter (PMT), triaxial (TXL), and CRS tests, are presented in Tables 2-4, respectively, for clays of worldwide locations with diverse geologic origins.

Table 2. Yield stress and strains of saturated clays from previous studies on PMT (loading phase).

\begin{tabular}{|c|c|c|c|c|c|c|c|c|c|}
\hline Sr. No. & $\begin{array}{l}\text { Yield Stress } \\
\left(\mathbf{P}_{\mathbf{y}}\right), \mathbf{k P a}\end{array}$ & $\begin{array}{c}\text { Pre-Yield } \\
\text { Strain } \\
\left(\varepsilon_{\text {pre }}\right)\end{array}$ & $\begin{array}{c}\text { Post-Yield } \\
\text { Strain } \\
\left(\varepsilon_{\text {post }}\right) \\
\end{array}$ & $\begin{array}{c}\text { Max } \\
\text { Pressure } \\
\left(\mathbf{P}_{\mathrm{L}}\right), \mathrm{kPa} \\
\end{array}$ & $\left(\varepsilon_{\text {post }} / \mathbf{P}_{\mathbf{y}}\right)$ & $\left(\varepsilon_{\text {post }} / \varepsilon_{\text {pre }}\right)$ & Type of Soil & PMT Type & Reference \\
\hline 1 & 535.7 & 0.00905 & 0.08523 & 809.5 & 0.00016 & 9.42 & Stiff Gault Clay & SBPM & $\begin{array}{c}\text { Windle and Wroth } \\
\text { (1977) [46] }\end{array}$ \\
\hline 2 & 806.4 & 0.02524 & 0.37006 & 870.2 & 0.00046 & 14.66 & $\begin{array}{l}\text { Stiff to very stiff } \\
\text { Gault Clay }\end{array}$ & FDP & $\begin{array}{c}\text { Houlsby and Withers } \\
\text { (1988) [47] }\end{array}$ \\
\hline $\begin{array}{l}3 \\
4\end{array}$ & $\begin{array}{l}654.5 \\
401.3 \\
\end{array}$ & $\begin{array}{l}0.02010 \\
0.01510\end{array}$ & $\begin{array}{l}0.08833 \\
0.08980\end{array}$ & $\begin{array}{l}818.2 \\
497.1 \\
\end{array}$ & $\begin{array}{c}0.000135 \\
0.00023\end{array}$ & $\begin{array}{l}4.39 \\
5.95\end{array}$ & $\begin{array}{l}\text { Soft to stiff } \\
\text { Fucino Clay }\end{array}$ & SBPM & $\begin{array}{c}\text { Ferreira and } \\
\text { Robertson (1992) [48] }\end{array}$ \\
\hline $\begin{array}{l}5 \\
6 \\
7\end{array}$ & $\begin{array}{l}437.5 \\
282.4 \\
123.7\end{array}$ & $\begin{array}{l}0.01616 \\
0.02070 \\
0.02424\end{array}$ & $\begin{array}{l}0.31767 \\
0.32525 \\
0.28282\end{array}$ & $\begin{array}{l}531.2 \\
330.2 \\
170.3\end{array}$ & $\begin{array}{l}0.00070 \\
0.00115 \\
0.00228\end{array}$ & $\begin{array}{l}19.66 \\
15.71 \\
11.67\end{array}$ & $\begin{array}{l}\text { Soft Bothkenner } \\
\text { clay }\end{array}$ & $\mathrm{CPM}$ & Nutt (1993) [49] \\
\hline 8 & 87.2 & 0.01923 & 0.16666 & 170.5 & 0.00191 & 8.67 & $\begin{array}{c}\text { Soft clay at } \\
\text { British Columbia }\end{array}$ & SBPM & \multirow{2}{*}{$\begin{array}{c}\text { Ferreira and } \\
\text { Robertson (1994) [50] }\end{array}$} \\
\hline 9 & 108.9 & 0.01794 & 0.25769 & 178.2 & 0.00236 & 14.36 & $\begin{array}{c}\text { Soft clay at } \\
\text { British Columbia }\end{array}$ & FDP & \\
\hline 10 & 225.0 & 0.02254 & 0.46470 & 329.0 & 0.00206 & 20.61 & Soft clay & FDP & $\begin{array}{c}\text { Rehman, Akbar and } \\
\text { Clarke (2011) [51] }\end{array}$ \\
\hline
\end{tabular}

$\mathrm{PMT}=$ pressuremeter; $\mathrm{SBPM}=$ self-boring pressuremeter; $\mathrm{FDP}=$ full-displacement pressuremeter; $\mathrm{CPM}=$ cone pressuremeter.

Table 3. Yield stress and strain of clays from previous studies on the triaxial test (loading phase).

\begin{tabular}{|c|c|c|c|c|c|c|c|c|c|}
\hline Sr. No. & $\begin{array}{l}\text { Yield Stress } \\
\left(\mathbf{P}_{\mathbf{y}}\right), \mathbf{k P a}\end{array}$ & $\begin{array}{c}\text { Pre-Yield } \\
\text { Strain } \\
\left(\varepsilon_{\text {pre }}\right)\end{array}$ & $\begin{array}{c}\text { Post-Yield } \\
\text { Strain } \\
\left(\varepsilon_{\text {post }}\right)\end{array}$ & $\mathbf{P}_{\max }, \mathbf{k P a}$ & $\varepsilon_{\text {post }} / \mathbf{P}_{\mathbf{y}}$ & $\varepsilon_{\text {post }} / \varepsilon_{\text {pre }}$ & Type of Soil & Test Type & Reference \\
\hline 1 & 33.2 & 0.00857 & 0.07071 & 28.9 & 0.00212 & 8.25 & \multirow{2}{*}{$\begin{array}{c}\text { Bothkenner Soft } \\
\text { Clay }\end{array}$} & Anisotropic & \multirow{2}{*}{$\begin{array}{l}\text { Hight, Bond, and } \\
\text { Legge (1992) [52] }\end{array}$} \\
\hline 2 & 49.6 & 0.01035 & 0.04501 & 45.1 & 0.00091 & 4.34 & & Undrained & \\
\hline 3 & 113.8 & 0.03148 & 0.15833 & 114.6 & 0.00139 & 5.03 & \multirow{6}{*}{$\begin{array}{l}\text { Soft Shanghai } \\
\text { clay } \\
\text { Soft Shanghai } \\
\text { clay }\end{array}$} & & \multirow{6}{*}{$\begin{array}{l}\text { Huang, Liu, and } \\
\text { Sheng (2011) [16] }\end{array}$} \\
\hline 4 & 80.7 & 0.03240 & 0.17963 & 81.5 & 0.00222 & 5.54 & & Isotropic & \\
\hline 5 & 67.6 & 0.02407 & 0.16851 & 61.5 & 0.00248 & 7.00 & & Undrained & \\
\hline 6 & 53.1 & 0.02777 & 0.21388 & 42.3 & 0.00403 & 7.70 & & & \\
\hline 7 & 86.1 & 0.01018 & 0.17685 & 65.0 & 0.00205 & 17.36 & & Anisotropic & \\
\hline 8 & 65.6 & 0.01388 & 0.190741 & 45.0 & 0.00336 & 13.73 & & Undrained & \\
\hline 9 & 1025.3 & 0.03839 & 0.119643 & 916.7 & 0.00011 & 3.12 & \multirow{4}{*}{$\begin{array}{l}\text { Boulder Clay, } \\
\text { Boulder, USA }\end{array}$} & & \multirow{4}{*}{$\begin{array}{c}\text { Mun et al. (2016) } \\
\text { [53] }\end{array}$} \\
\hline 10 & 703.4 & 0.02881 & 0.120339 & 908.3 & 0.00017 & 4.18 & & Unconsolidated & \\
\hline 11 & 225.1 & 0.01785 & 0.133929 & 441.6 & 0.00059 & 7.50 & & Undrained & \\
\hline 12 & 166.7 & 0.01607 & 0.133036 & 301.4 & 0.00079 & 8.28 & & & \\
\hline 13 & 131.1 & 0.00833 & 0.0638889 & 164.4 & 0.00048 & 7.67 & \multirow{2}{*}{$\begin{array}{l}\text { Low plastic Soft } \\
\text { Clay }\end{array}$} & Isotropic & \multirow{2}{*}{$\begin{array}{c}\text { Gluchowski et al. } \\
\text { (2019) [54] }\end{array}$} \\
\hline 14 & 61.1 & 0.00444 & 0.0672222 & 120.8 & 0.00109 & 15.13 & & Undrained & \\
\hline 15 & 246.1 & 0.03522 & 0.164773 & 267.3 & 0.00066 & 4.68 & \multirow{4}{*}{$\begin{array}{l}\text { Expansive Clay, } \\
\text { Nanyang, China }\end{array}$} & & \multirow{4}{*}{ Dai et al. (2020) [55] } \\
\hline 16 & 221.1 & 0.03181 & 0.167045 & 209.6 & 0.00075 & 5.25 & & Consolidated & \\
\hline 17 & 182.7 & 0.02386 & 0.173864 & 176.9 & 0.00095 & 7.29 & & Undrained & \\
\hline 18 & 115.4 & 0.02045 & 0.176136 & 140.4 & 0.00152 & 8.61 & & & \\
\hline 19 & 133.7 & 0.01619 & 0.0647619 & 101.2 & 0.00048 & 4.00 & \multirow{4}{*}{ Soft Marine Clay } & & \multirow{4}{*}{$\begin{array}{l}\text { Tsuchida et al. } \\
\text { (2020) [56] }\end{array}$} \\
\hline 20 & 143.5 & 0.01809 & 0.072381 & 103.2 & 0.00050 & 4.00 & & Consolidated & \\
\hline 21 & 158.3 & 0.02095 & 0.0619048 & 115.4 & 0.00039 & 2.95 & & Undrained & \\
\hline 22 & 156.2 & 0.02201 & 0.0770102 & 93.3 & 0.00029 & 3.50 & & & \\
\hline
\end{tabular}


Table 4. Yield stress and strain of clays from previous studies on the CRS test (loading phase).

\begin{tabular}{|c|c|c|c|c|c|c|c|c|}
\hline Sr. No. & $\begin{array}{l}\text { Yield Stress } \\
\left(\mathbf{P}_{\mathbf{y}}\right), \mathrm{kPa}\end{array}$ & $\begin{array}{l}\text { Pre-Yield } \\
\text { Strain }\left(\varepsilon_{\text {pre }}\right)\end{array}$ & $\begin{array}{c}\text { Post-Yield } \\
\text { Strain }\left(\varepsilon_{\text {post }}\right)\end{array}$ & $\begin{array}{c}\text { Max. } \\
\text { Pressure } \\
P_{\max }, \mathrm{kPa}\end{array}$ & $\varepsilon_{\text {post }} / \mathbf{P}_{\mathbf{y}}$ & $\varepsilon_{\text {post }} / \varepsilon_{\text {pre }}$ & Type of Soil & Reference \\
\hline 1 & 76.3 & 0.03022 & 0.23022 & 184.5 & 0.00302 & 7.61 & \multirow{4}{*}{$\begin{array}{l}\text { Gloucester clay } \\
\text { Canada }\end{array}$} & \multirow{4}{*}{$\begin{array}{c}\text { Leroueil, Samson, } \\
\text { and Bozozuk (1983) } \\
{[13]}\end{array}$} \\
\hline 2 & 90.1 & 0.04002 & 0.21955 & 241.6 & 0.00244 & 5.48 & & \\
\hline 3 & 74.5 & 0.01511 & 0.22044 & 199.1 & 0.00296 & 14.58 & & \\
\hline 4 & 106.7 & 0.02755 & 0.18844 & 238.9 & 0.00177 & 6.83 & & \\
\hline 5 & 117.4 & 0.00895 & 0.217911 & 235.6 & 0.00186 & 2.43 & \multirow{2}{*}{$\begin{array}{l}\text { Batiscan clay } \\
\text { St. Cesaire clay }\end{array}$} & \multirow{2}{*}{$\begin{array}{c}\text { Leroueil et al. (1985) } \\
\text { [57] }\end{array}$} \\
\hline 6 & 144.7 & 0.05447 & 0.18059 & 239.4 & 0.00125 & 3.32 & & \\
\hline 7 & 101.5 & 0.04010 & 0.24002 & 611.6 & 0.00236 & 5.98 & \multirow{2}{*}{ Winnipeg clay } & \multirow{2}{*}{$\begin{array}{c}\text { Grahams, Crooks, } \\
\text { and Lau (1988) [10] }\end{array}$} \\
\hline 8 & 98.3 & 0.04571 & 0.08653 & 151.7 & 0.00088 & 1.89 & & \\
\hline 9 & 210.3 & 0.02782 & 0.05217 & 351.7 & 0.00025 & 1.87 & \multirow{2}{*}{$\begin{array}{l}\text { Norwegian } \\
\quad \text { Clay }\end{array}$} & \multirow{2}{*}{$\begin{array}{c}\text { Lunne et al. (2008) } \\
\text { [58] }\end{array}$} \\
\hline 10 & 157.1 & 0.04170 & 0.11915 & 246.4 & 0.00076 & 2.85 & & \\
\hline 11 & 59.5 & 0.03889 & 0.26528 & 305.4 & 0.00446 & 6.82 & \multirow{5}{*}{$\begin{array}{l}\text { Ariake clay, } \\
\text { Japan }\end{array}$} & \multirow{5}{*}{ Jia et al. (2010) [59] } \\
\hline 12 & 30.2 & 0.03764 & 0.24167 & 176.2 & 0.00800 & 6.42 & & \\
\hline 13 & 30.2 & 0.03751 & 0.25417 & 204.1 & 0.00842 & 6.78 & & \\
\hline 14 & 102.5 & 0.04161 & 0.25138 & 503.6 & 0.00245 & 6.04 & & \\
\hline 15 & 50.2 & 0.04458 & 0.25278 & 261.3 & 0.00504 & 5.67 & & \\
\hline 16 & 110.3 & 0.07571 & 0.20857 & 180.3 & 0.00189 & 2.75 & $\begin{array}{l}\text { Maxico City } \\
\text { clay }\end{array}$ & $\begin{array}{c}\text { Diaz-Rodriguez, } \\
\text { Tonix, and Carrizales } \\
\text { (2017) [60] }\end{array}$ \\
\hline
\end{tabular}

The bilinear plotting technique was applied to determine the yield stress for the data of PMT, TXL and CRS tests from previous studies. This method describes the intersection of two straight line approximations, i.e., one from the pre-yield phase and another from the post-yield phase of stress-strain curves of PMT, TXL, and CRS tests conducted in clay.

The extent of post-yield strain is related to the pre-yield strain and yield stress for clays. For different values of yield stress and pre-yield strain, there are different values of post-yield strain which requires normalization so that clear effect of maximum pressure $\left(P_{\max }\right)$ due to embankment height can be evaluated in the form of post-yield strain.

PMT, TXL, and CRS tests are significant when studying the yielding behavior of clays. The yield point and yield zones in clay can be effectively observed in PMT and TXL stressstrain curves [61,62]. CRS tests are considered as standard for the evaluation of effective yield stress $\left(\sigma_{y}^{\prime}\right)$ of clays whereas $\sigma_{y}^{\prime}$ from in situ tests should be compared with standard oedometer tests (e.g., CRS) to validate proposed empirical correlations. The CRS test on clays critically depends on the strain rate and provides continuous data points as compared with incrementally loaded (IL) oedometer tests [63]. Both the loading and unloading stress-strain curves can be analyzed for the yield point in PMT, TXL, and CRS tests.

It is well established that strain energy is released during the unloading in embankment slopes and, resultantly, the progressive failure is observed [64]. Present research simulates to the release of strain energy in slopes in the way that the lowering in strain energy (work) occurs in the unloading phases of PMT, TXL, and CRS tests. Hence, the unloading phase of these tests is significant when evaluating yielding behaviors and large failure displacements for embankments where the embankment slope is unloaded due to excavation.

The specific level of dry density, moisture content, and plasticity index (PI) are the index properties to be studied for the stability analysis of embankments constructed on very soft to soft clays. The increase in density causes an increase in shear strength, whereas an increase in moisture makes the clay soft, resulting in a lower shear strength. It is necessary to study the changes in the profiles of dry density, moisture, and the PI of clay for the design of embankments.

Previous studies $[6,17-31,64]$ on the failure of embankments explored the extent of post-failure movement of the toe and the settlement of apex of embankments in the case of very soft to soft clays due to pressure exerted by the increase in height of the embankment. Previous studies did not compare the loading and unloading behaviors of clay in the same 
test. However, this research presents the novel correlations based on loading and unloading behavior in stress-strain curves of field tests (PMT) and laboratory tests (triaxial and CRS) to determine the critical post-yield failure strain before onset of embankment failure. Hence, this study will be useful to take prior safety measures to reduce the post-failure damages at and around the critical portion of the road or railway embankment for loading and unloading conditions of the embankments.

Very few studies have predicted post-yield strains $\left(\varepsilon_{\text {post }}\right)$ using pre-yield strain $\left(\varepsilon_{\text {pre }}\right)$, yield stress $\left(\sigma_{y}^{\prime}\right)$, and maximum applied pressure $\left(P_{\max }\right)$ for the loading and unloading phases of PMT, TXL, and CRS tests. This research is intended to explore the yielding behavior of very soft to very stiff saturated clay and is devoted to investigate the following specific aspects:

(i) To evaluate yield stress $\left(\sigma^{\prime} y\right)$ by the work method [65] and determine the pre-yield strains $\left(\varepsilon_{\text {pre }}\right)$ and post-yield strains $\left(\varepsilon_{\text {post }}\right)$ from loading and unloading phases of stress-strain curves;

(ii) To explore the range of exponential critical post-yield strains $\left(\varepsilon_{\text {post }}\right)$ in loading and unloading phases of very soft to soft clay;

(iii) To develop correlations for the prediction of post-yield strains $\left(\varepsilon_{\text {post }}\right)$ from yield stress $\left(\sigma_{y}^{\prime}\right)$, pre-yield strains $\left(\varepsilon_{\text {pre }}\right)$, and maximum applied pressure $\left(P_{\max }\right)$ for loading and unloading curves;

(iv) To benchmark this research, data were validated by past studies and by conducting testing on a separate saturated clay site.

\section{Materials and Methods}

An alluvial deposit comprising stratigraphy, divided into four units, i.e., very soft, soft, stiff, and very stiff saturated clay with medium plasticity, was selected in Lahore, Pakistan for the geotechnical characterization by field testing (PMT) and laboratory testing (triaxial and CRS) on undisturbed soils retrieved from the field.

Experimentation was performed at eighteen points in an area of about $100 \mathrm{~m} \times 250 \mathrm{~m}$ size, as per layout the plan shown in Figure 2. The soil investigation approach was adopted to select a particular member of the soil group to test in a variety of test conditions. For this purpose, a comprehensive experimentation program (Figure 2) was planned for field sampling and in situ testing of site strata. Borehole drilling was conducted to retrieve one hundred and eighty undisturbed samples (UDSs) from eighteen boreholes of $10 \mathrm{~m}$ depth each. The pattern of boreholes is shown in Figure 2a and a plan of in situ PMTs and UDSs is presented in Figure $2 \mathrm{~b}$.

The drilling for UDSs was conducted by rotary drilling rig. As the quality of undisturbed samples depends on the precision of samplers for high-quality stress-strain curves, high-quality UDSs were taken by steel tubes by slow pressure on sampler during rotary drilling (ASTM D5783) [66]. The UDSs were retrieved at the average rotation speed of rotary drilling rig (ASTM D5783) [66], i.e., $42 \mathrm{rpm}$, and bentonite was used as a drilling mud with a 12 liters/min pumping speed to shift the material cuttings out of the borehole. Careful efforts were made to preserve the in situ arrangement of soil particles during undisturbed soil sampling using thin-walled steel tubes (ASTM D1587) [67]. The UDSs were transported to the laboratory according to ASTM D4220 [68]. Two additional boreholes $\left(\mathrm{B}_{1}\right.$ and $\left.\mathrm{B}_{2}\right)$ were drilled up to a $20 \mathrm{~m}$ depth to determine the ground water table (GWT). The GWT was observed at a $15.7 \mathrm{~m}$ depth over an observation time of $72 \mathrm{~h}$. 


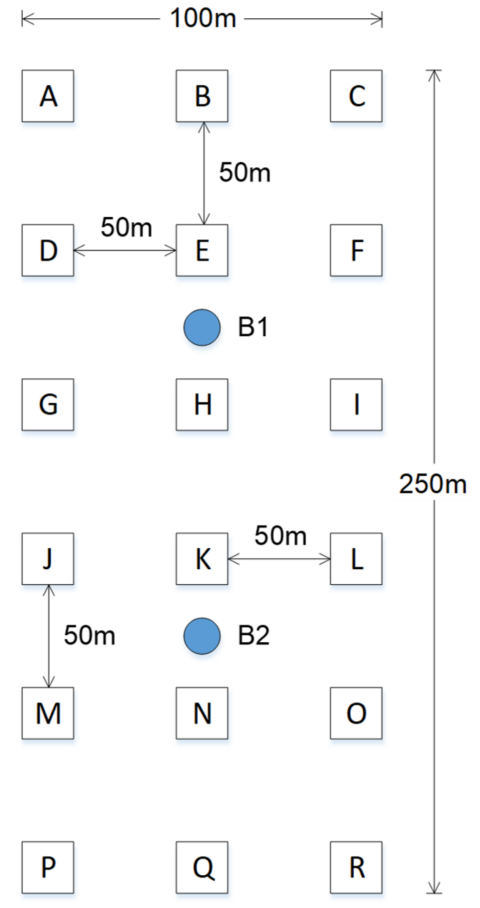

(a)

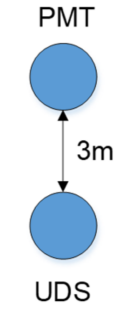

Point $\mathrm{A}$

(b)

Figure 2. (a) Location plan of drilling/field testing points (b) plan of PMTs and UDSs.

A comprehensive field study was planned which comprised one hundred and eighty prebored pressuremeter (PMT) tests at site. The potential use of PMT as a tool to analyze the stress-strain behavior of clay is further explored for pre-yield strain and post-yield strain. Prebored pressuremeter (PMT) can be used to precisely determine the stress-strain curves of soil strata [69,70]. PMT tests were conducted as per ASTM D4719 in prebored boreholes at $1 \mathrm{~m}$ to $10 \mathrm{~m}$ depths. The drilling of boreholes for PMT testing was conducted by a mechanical drilling system with specially designed slotted sampler and an outer diameter of $49 \mathrm{~mm}$, developed by [69,70], due to which the smooth surface of borehole walls with minimum disturbance (ASTM D5434 [71]) was achieved as a prerequisite for PMT testing according to ASTM D4719 [72]. The boreholes were prepared for acceptable smooth surface and a vertically aligned test cavity was used to satisfy the borehole diameter requirements mentioned in ASTM D 4719 [72], which are as follows:

$1.03 \mathrm{D}<\mathrm{D}_{\mathrm{H}}<1.2 \mathrm{D}$

$\left(\mathrm{D}=\right.$ diameter of the probe and $\mathrm{D}_{\mathrm{H}}=$ diameter of the hole or test cavity).

The procedure outlined in ASTM D1452 [73] was adopted for extracting disturbed samples. The PMT equipment used in this research was the strain arm type with a length of $305 \mathrm{~mm}$ and an outer diameter of $48.2 \mathrm{~mm}$. A PMT cylindrical probe was placed in a prebored borehole at specific depths, and the membrane of the probe was expanded with nitrogen gas to compress the wall of borehole to obtain stress-strain curves. The data logger and the pressure system were attached to the apparatus.

One hundred and eighty stress-controlled PMTs were performed at a very slow to slow rate of pressure application, ranging from $0.45 \mathrm{kPa} / \mathrm{min}$ to $4 \mathrm{kPa} / \mathrm{min}$ to maintain the low rate of strain in the range of $0.18 \% / \mathrm{min}$ to $0.21 \% / \mathrm{min}$, which corresponds to the impending failure condition in embankments. The adopted strain rate in this study corresponds to the range of critical strain rate of the embankments for impending failure condition [74]. The hall-effect transducer (HET) was installed inside the probe to measure the displacement of the membrane from the surface of the probe. A pressure transducer 
was used to measure the pressure inside the PMT membrane. The membrane and the HET were calibrated before the start of experimentation.

One hundred and eighty undisturbed samples (UDS) were subjected to laboratory testing. The clay samples retrieved from UDS were tested for the saturation level. Here, it was found that the strata up to a $10 \mathrm{~m}$ depth were in a saturated condition. The laboratory tests, i.e., gradation analysis for the grain sizes of particles comprising sand, silt, and clay (ASTM D6913) [75], as well as the dry density of soil $\left(\gamma_{d}\right)$, were used by weighing and oven-drying the soil samples taken from the UDS tube (ASTM D7263 [76]). Furthermore, Atterberg limits, including the liquid limit and the plastic limit for the soil passing \#40 sieve (ASTM D4318 [77]); the moisture content (MC) of the soil taken from UDS by weighing the natural and oven-dried soil (ASTM D2216 [78]); soil classification for the samples retrieved from $1 \mathrm{~m}$ to $10 \mathrm{~m}$ depths on the basis of grain size analysis and Atterberg limits (ASTM D2487 [79]); and the specific gravity $\left(G_{s}\right)$ of soil were all determined for the UDS (ASTM D854 [80].

Undisturbed samples (UDS) in thin-walled tubes were preserved in a controlled humidity room to avoid moisture loss. Samples for triaxial tests were extruded from thinwalled tubes into a split mold with a diameter of $38 \mathrm{~mm}$ and a length of $76 \mathrm{~mm}$. The samples were installed in the triaxial cells and then subjected to a saturation phase up to $B=0.98$, where $B$ is the Skempton's parameter for assessment of saturation. Then, the samples were subjected to effective consolidation stress that was equal to the overburden stress. An undrained condition for anisotropically consolidated undrained $\left(\mathrm{CK}_{\mathrm{o}} \mathrm{UC}\right)$ triaxial tests was applied. Strain-controlled triaxial tests were performed according to ASTM D4767 [81]. Monotonic loading was applied throughout the shearing phase. The effective confining pressure was taken equal to the overburden pressure for samples from different depths. One hundred and eighty undrained anisotropic triaxial compression $\left(\mathrm{CK}_{\mathrm{o}} \mathrm{UC}\right)$ strain-controlled tests were performed on the UDS, as per ASTM D4767 [81]. Triaxial tests were conducted at a strain rate of $0.19 \% / \mathrm{min}$ for comparison with average strain rate of pressuremeter tests for reasonable comparison of yield behavior.

One hundred and eighty controlled-rate-of-strain (CRS) consolidation tests (ASTM D4186) [82] were performed on the undisturbed soil samples (UDS) at a specific strain rate of $0.19 \% / \mathrm{min}$. This choice was only made to attain the matching strain with the strain rate for initiation of the failure of embankments. The sample diameter of $63.7 \mathrm{~mm}$ and thickness of $20 \mathrm{~mm}$ were selected for the use of specimens in CRS tests. The CRS tests economically and promptly determined the consolidation properties of the clays. The strain rate was also selected for the incrementally loaded consolidation tests.

\section{Results}

Figure 3 shows the typical grain size distribution results of soil strata encountered at sites up to $10 \mathrm{~m}$ deep. The soil classification (ASTM D2487 [79]) shows that the strata up to $10 \mathrm{~m}$ depth are "lean clay" with a medium plasticity index (PI). Figure 4 shows the profiles of moisture content $(\mathrm{MC})$, dry density $\left(\gamma_{\mathrm{d}}\right)$, plasticity index $(\mathrm{PI})$, and SPT blows for the soil strata up to $10 \mathrm{~m}$ deep.

The MC ranges from $26 \%$ to $36 \%$ in a decreasing trend; $\gamma_{\mathrm{d}}$ ranges from $1.31 \mathrm{~g} / \mathrm{cm}^{3}$ to $1.63 \mathrm{~g} / \mathrm{cm}^{3}$ in an increasing trend; and PI ranges from $19 \%$ to $31 \%$, showing the decreasing trend from the surface to a $10 \mathrm{~m}$ depth. The average value of $G_{s}$ is 2.73 for the soil encountered up to a $10 \mathrm{~m}$ depth. Very soft clay was observed up to a $2 \mathrm{~m}$ depth, whereas soft clay, stiff clay, and very stiff clay strata were encountered from a $2 \mathrm{~m}$ to $5 \mathrm{~m}$ depth, a $5 \mathrm{~m}$ to $7.5 \mathrm{~m}$ depth, and a $7.5 \mathrm{~m}$ to $10 \mathrm{~m}$ depth, respectively. 


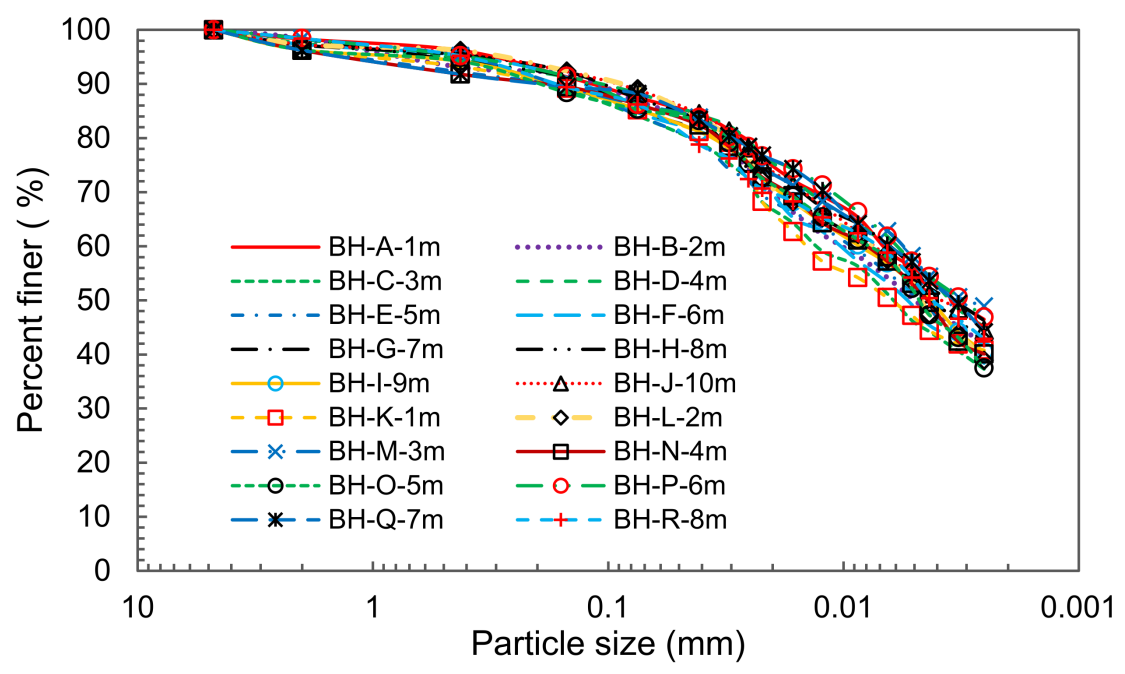

Figure 3. Typical grain size distribution curves of field strata up to $10 \mathrm{~m}$ deep.

Soil

stratigraphy

Moisture content, $\%$

\begin{tabular}{|l|}
\hline $\begin{array}{c}\text { Very } \\
\text { soft } \\
\text { clay }\end{array}$ \\
\hline Soft \\
clay \\
Stiff \\
clay \\
\hline $\begin{array}{l}\text { Very } \\
\text { stiff } \\
\text { clay }\end{array}$ \\
\hline
\end{tabular}

Dry density,

$$
\mathrm{g} / \mathrm{cm}^{3}
$$
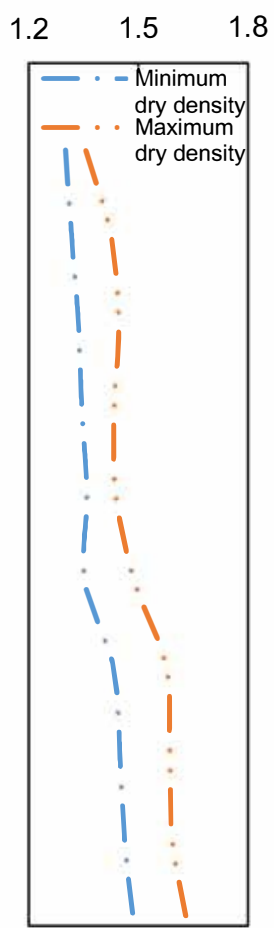

Plasticity Index $(\mathrm{PI}), \%$

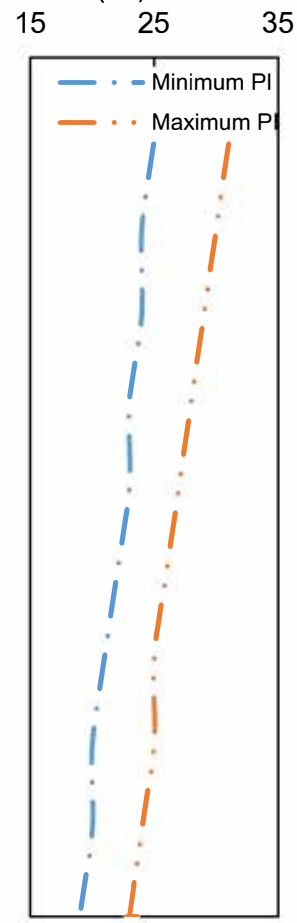

SPT blows

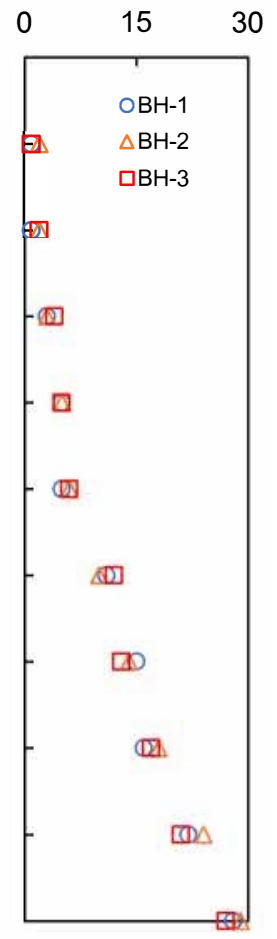

Figure 4. Profiles of moisture content, dry density, plasticity index, and SPT blows of the strata on the site.

The yield stress is precisely determined with a bilinear plotting technique by use of work-effective pressure $\left(\mathrm{W}-\mathrm{p}^{\prime}\right)$ curves, as per procedure mentioned in [83] from the data of PMT, TXL, and CRS tests. This method describes the intersection of two straight line approximations, i.e., one from the pre-yield phase and another from the post-yield phase [83] from stress-strain curves of PMT, TXL, and CRS tests conducted in clay.

Typical loading and unloading curves of PMT, TXL and CRS tests are presented in Figure 5 which show the yield stress at $1 \mathrm{~m}, 5 \mathrm{~m}$, and $10 \mathrm{~m}$ depths. The test curves are presented in the form of strain versus $\mathrm{p}^{\prime}$ (log scale) for purpose of comparison of shape of curves. It was observed that shape of stress-strain curves becomes round at the maximum curvature which makes it difficult to determine yield stress $\left(\sigma^{\prime}{ }_{y}\right)$ by using graphical method 
at simple stress-strain curves. Hence, pre-yield and post-yield strains from PMT test curves are evaluated by work method i.e., determining effective yield stress $\left(\sigma_{\mathrm{y}}^{\prime}\right)$ at the intersection of two straight lines. The adopted strain range in PMT, TXL and CRS tests is very narrow, hence the effects of strain rate on soil behaviour are not discussed in this research.

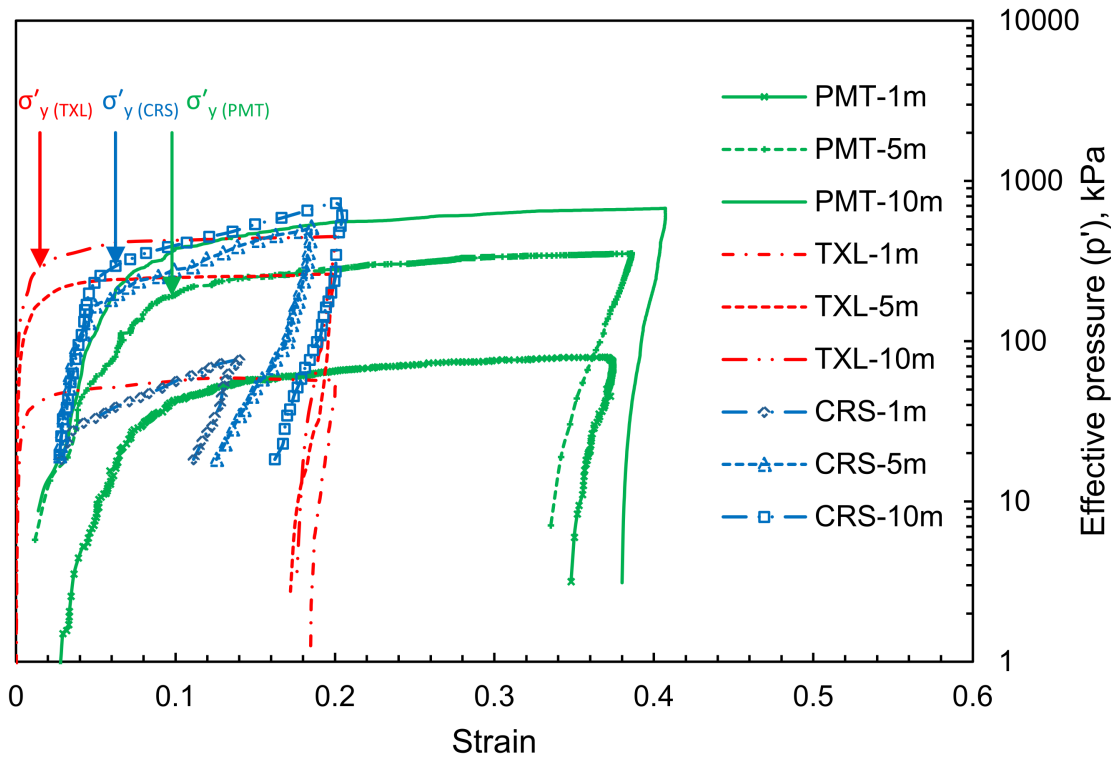

Figure 5. Yield stress at PMT, TXL, and CRS typical curves at $1 \mathrm{~m}, 5 \mathrm{~m}$, and $10 \mathrm{~m}$ depths.

The work per unit volume versus effective pressure (W versus $\mathrm{p}^{\prime}$ ) graphs of PMT at $1 \mathrm{~m}, 5 \mathrm{~m}$, and $10 \mathrm{~m}$ depths, as presented in Figure 6 , show yield stresses $\left(\sigma_{\mathrm{y}}^{\prime}\right)$ of $38 \mathrm{kPa}$, $206 \mathrm{kPa}$, and $311 \mathrm{kPa}$, respectively, in the loading phases. Figure 6 shows the abrupt change in slope of $\mathrm{W}-\mathrm{p}^{\prime}$ praph at the point of yield stress. The unloading behaviour of PMT curves at $1 \mathrm{~m}, 5 \mathrm{~m}$, and $10 \mathrm{~m}$ depths are analyzed by the $\mathrm{W}-\mathrm{p}^{\prime}$ trend, which resulted in yield stresses of $40 \mathrm{kPa}, 212 \mathrm{kPa}$, and $304 \mathrm{kPa}$, respectively, as shown in Figure 7.

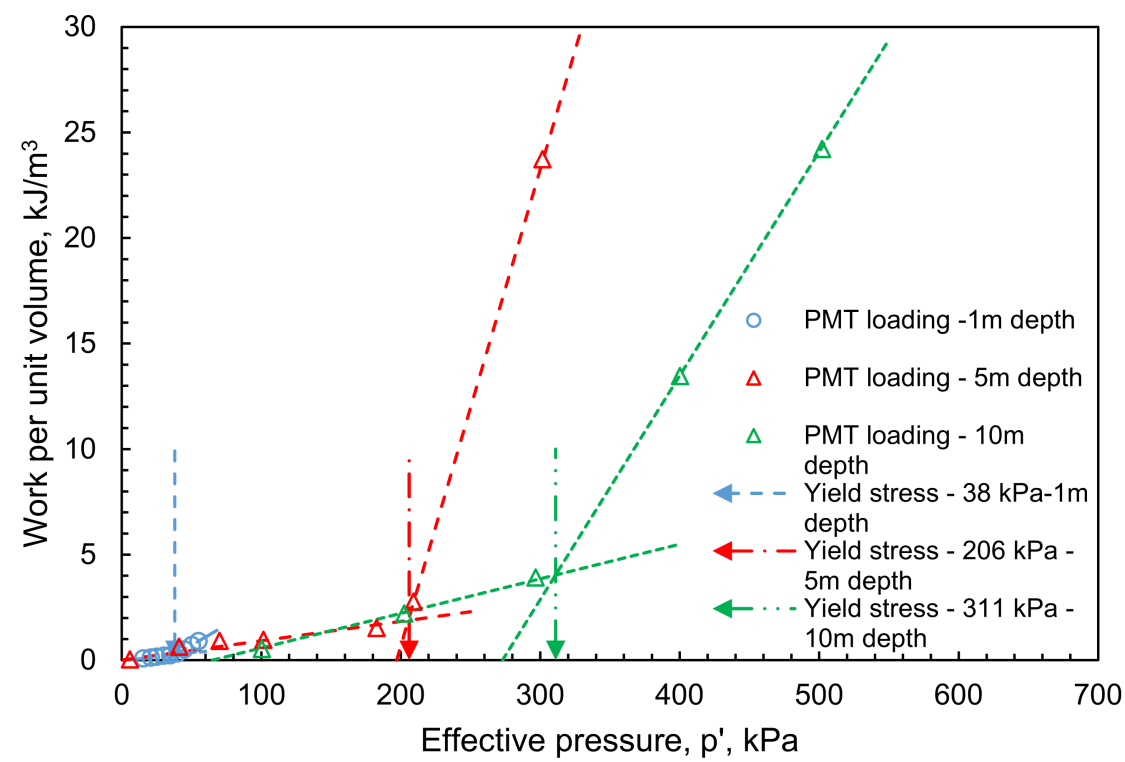

Figure 6. Yield stress from PMT typical curves (loading phase) at $1 \mathrm{~m}, 5 \mathrm{~m}$, and $10 \mathrm{~m}$ depths. 


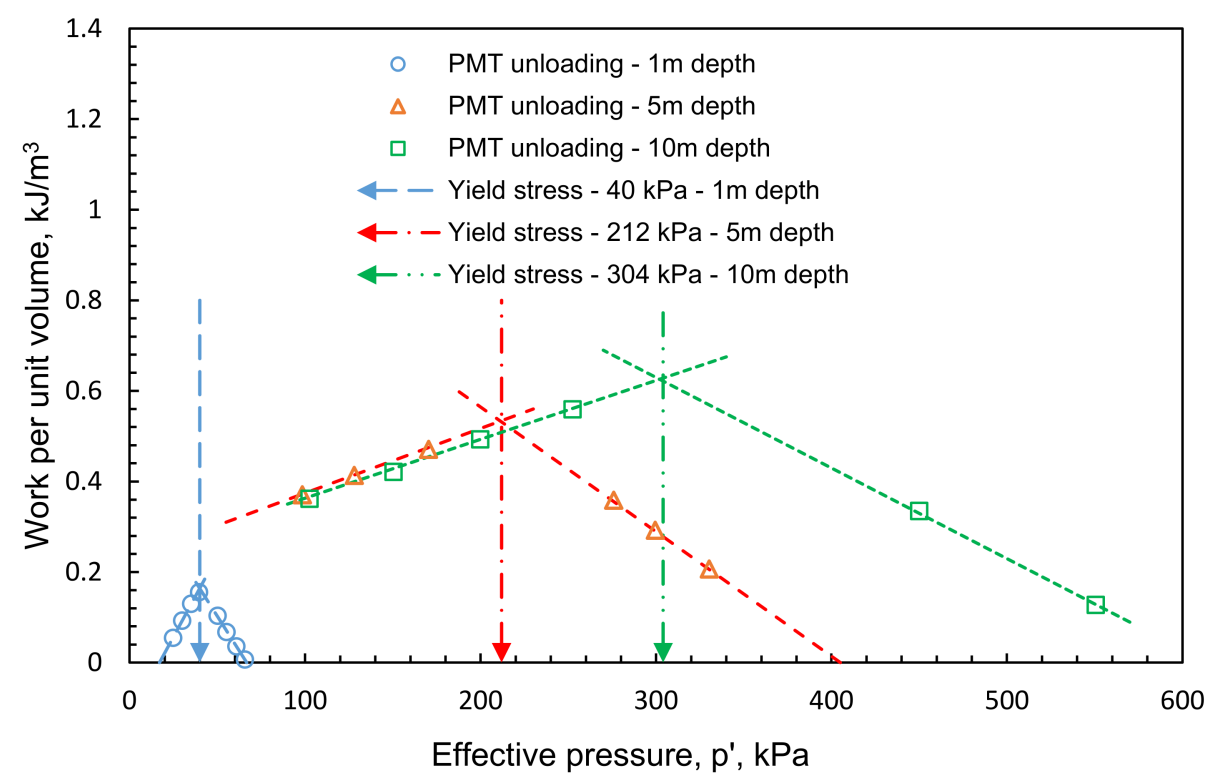

Figure 7. Yield stress from PMT typical curves (unloading phase) at $1 \mathrm{~m}, 5 \mathrm{~m}$, and $10 \mathrm{~m}$ depths.

The yield stresses $\left(\sigma_{y}^{\prime}\right)$ for the triaxial curves at $1 \mathrm{~m}, 5 \mathrm{~m}$, and $10 \mathrm{~m}$ depths (Figure 8) were analyzed by work method ( $\mathrm{W}$ versus $\mathrm{p}^{\prime}$ ) and resulted in the $\sigma_{\mathrm{y}}^{\prime}$ values of $39 \mathrm{kPa}$, $200 \mathrm{kPa}$, and $265 \mathrm{kPa}$, respectively, for the loading phases. The unloading phases of PMT curves at $1 \mathrm{~m}, 5 \mathrm{~m}$, and $10 \mathrm{~m}$ depths showed $\sigma_{\mathrm{y}}^{\prime}$ values of $37.3 \mathrm{kPa}, 207 \mathrm{kPa}$, and $278 \mathrm{kPa}$, respectively, as presented in Figure 9.

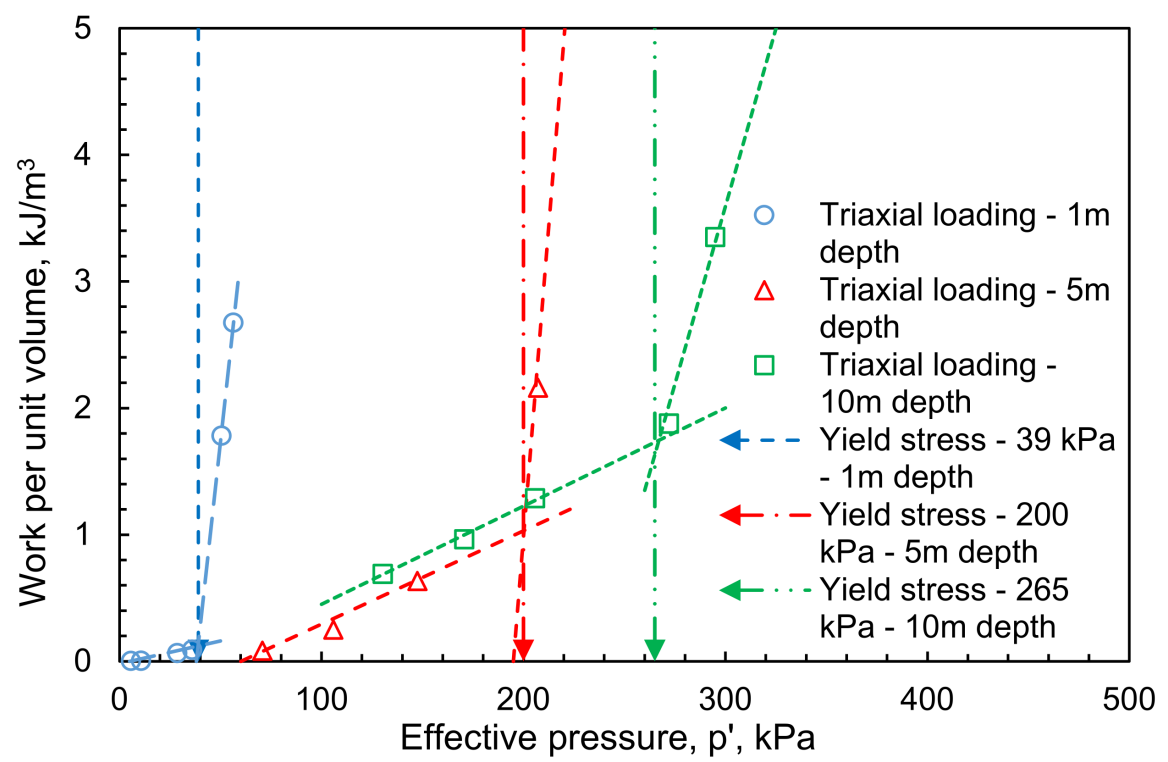

Figure 8. Yield stress from TXL typical curves (loading phase) at $1 \mathrm{~m}, 5 \mathrm{~m}$, and $10 \mathrm{~m}$ depths. 


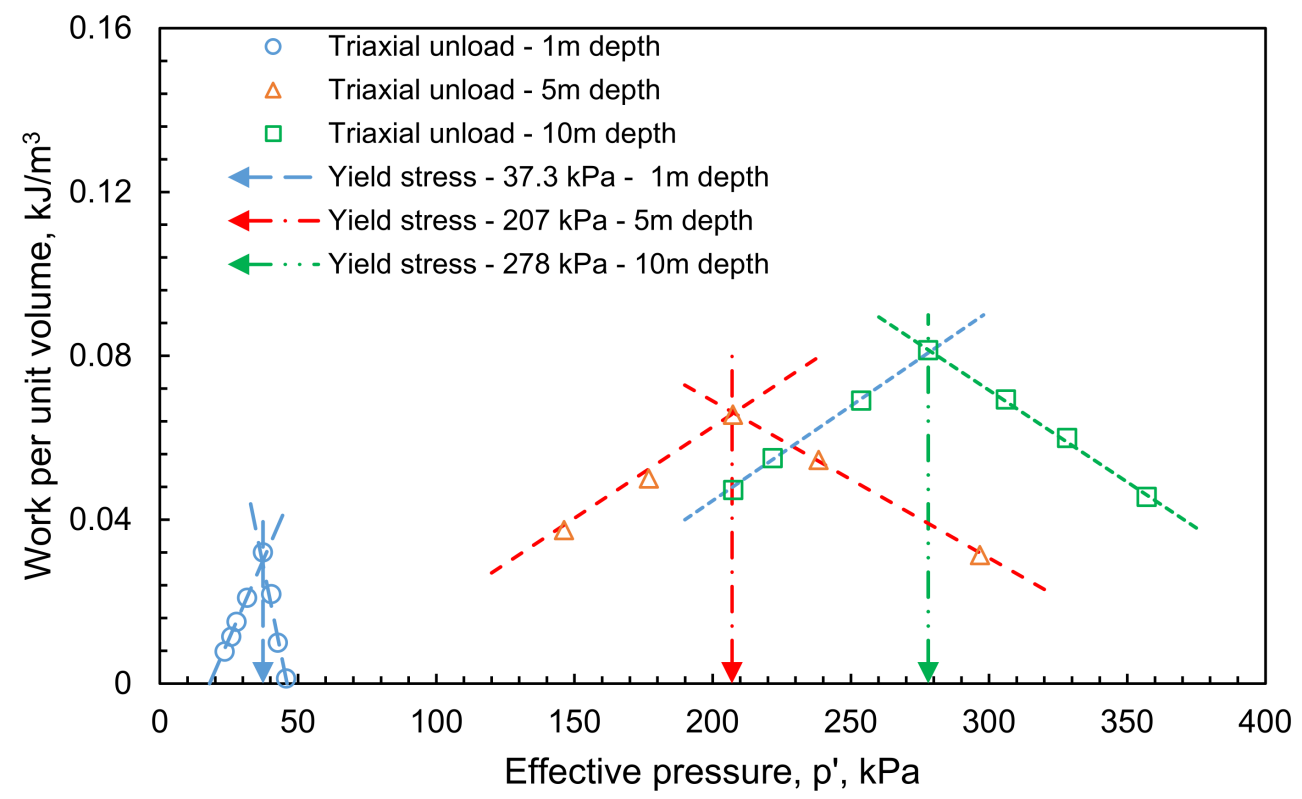

Figure 9. Yield stress from TXL typical curves (unloading phase) at $1 \mathrm{~m}, 5 \mathrm{~m}$, and $10 \mathrm{~m}$ depths.

Constant-rate-of-strain (CRS) stress-strain curves of $1 \mathrm{~m}, 5 \mathrm{~m}$, and $10 \mathrm{~m}$ depths are analyzed by the work method which showed $\sigma_{y}^{\prime}$ values of $33.2 \mathrm{kPa}, 208 \mathrm{~Pa}$, and $284 \mathrm{kPa}$ in the loading phases (Figure 10) and $33.8 \mathrm{kPa}, 206 \mathrm{kPa}$, and $298 \mathrm{kPa}$ (Figure 11) in the unloading phases, respectively.

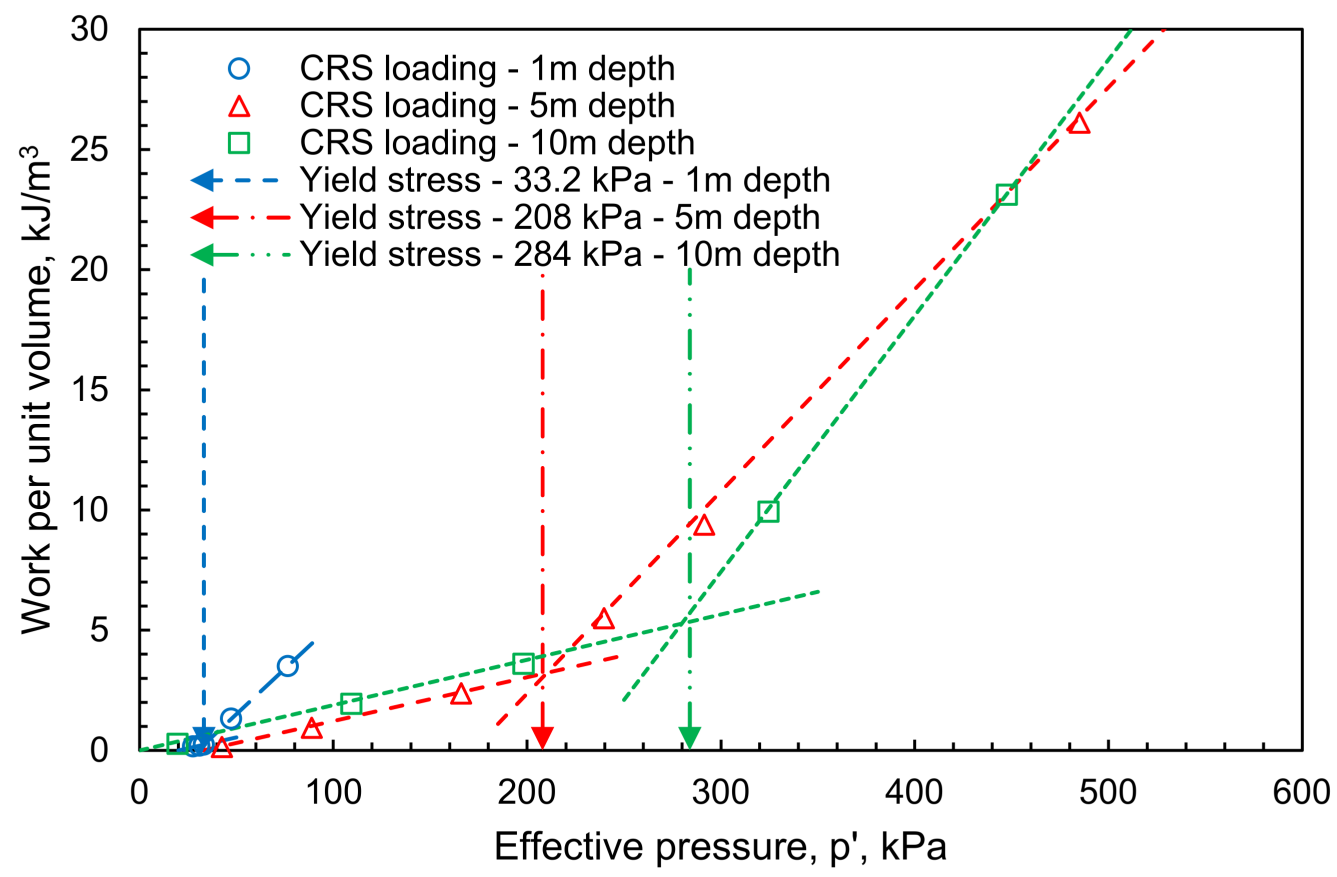

Figure 10. Yield stress from CRS typical curves (loading phase) at $1 \mathrm{~m}, 5 \mathrm{~m}$, and $10 \mathrm{~m}$ depths. 


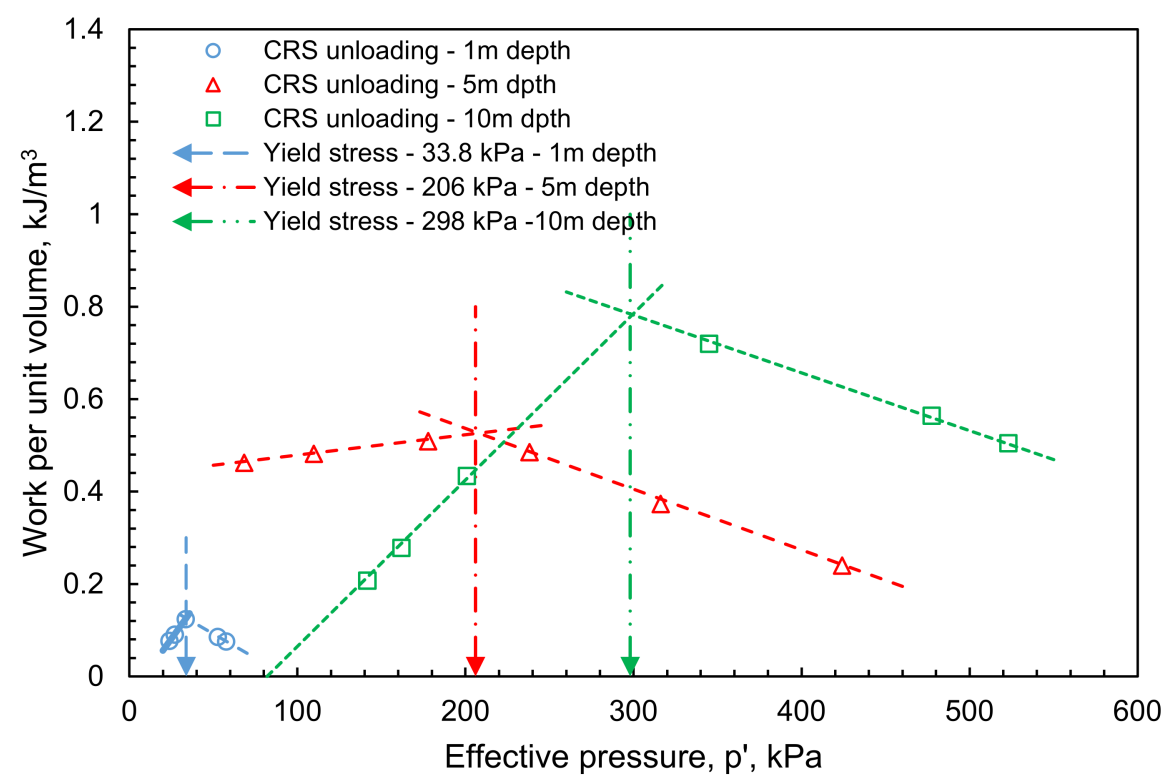

Figure 11. Yield stress from CRS typical curves (unloading phase) at $1 \mathrm{~m}, 5 \mathrm{~m}$, and $10 \mathrm{~m}$ depths.

After the evaluation of $\sigma_{y}^{\prime}$ from PMT, TXL, and CRS stress-strain curves, the pre-yield strain $\left(\varepsilon_{\text {pre }}\right)$ and post-yield strain $\left(\varepsilon_{\text {post }}\right)$ were determined to compare these three types of test curves.

\section{Discussion}

Relations between post-yield strain/yield stress [i.e., $\varepsilon_{\text {post PMT }} / \sigma_{y}^{\prime}$ ] versus $P_{\max }$ (the maximum pressure observed in stress-strain curves) are presented in Figures 12 and 13 for the loading and unloading phases, respectively. The exponential rise in post-yield strain starts from $\varepsilon_{\text {post PMT }} / \sigma_{\text {y }}^{\prime}$ values of 0.0017 (loading) and 0.00019 (unloading), which points out the $\mathrm{P}_{\max }$ of about $201 \mathrm{kPa}$ (loading) and $202 \mathrm{kPa}$ (unloading).

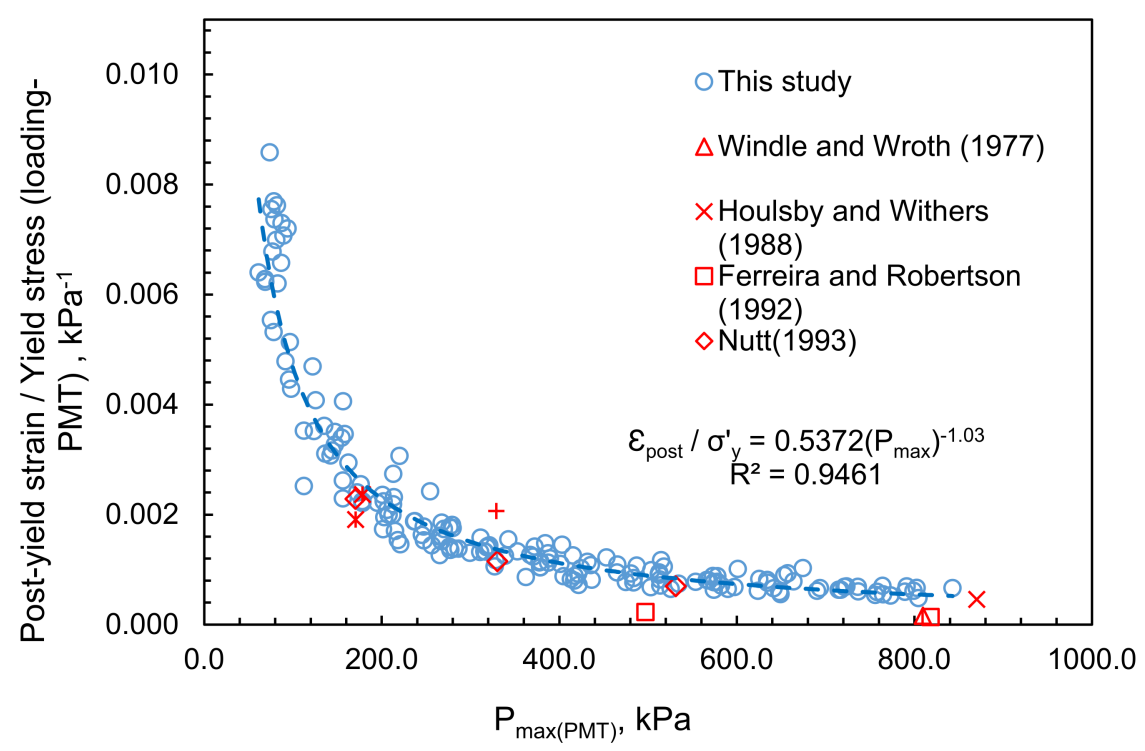

Figure 12. Post-yield strain/yield stress versus maximum pressure (PMT loading phase). 


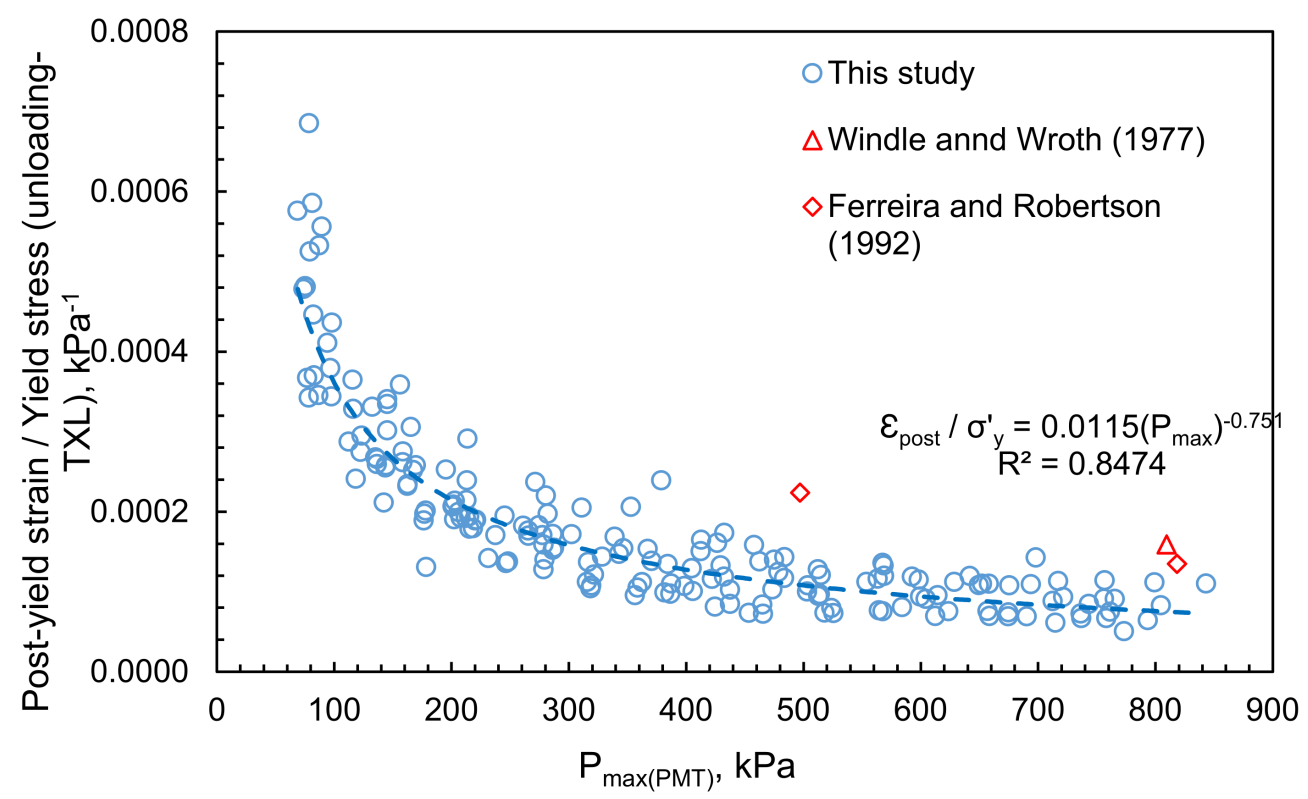

Figure 13. Post-yield strain/yield stress versus maximum pressure (PMT unloading phase).

Figures 14 and 15 present the relations of post-yield/pre-yield strains (i.e., $\varepsilon_{\text {post PMT }} /$ $\varepsilon_{\text {pre PMT }}$ ) versus $\mathrm{P}_{\max }$ in the loading and unloading phases, respectively, for PMT test curves which depict that $\left(\varepsilon_{\text {post PMT }} / \varepsilon_{\text {pre PMT }}\right)$ values abruptly increase at the value of about 6.96 (loading) and 8.47 (unloading), corresponding to a $\mathrm{P}_{\max }$ of about $207 \mathrm{kPa}$ (loading) and $213 \mathrm{kPa}$ (unloading). The relations proposed in Figures 12-15 are validated by renowned past studies (Table 2) for the loading phase of pressuremeter (PMT) tests in clays.

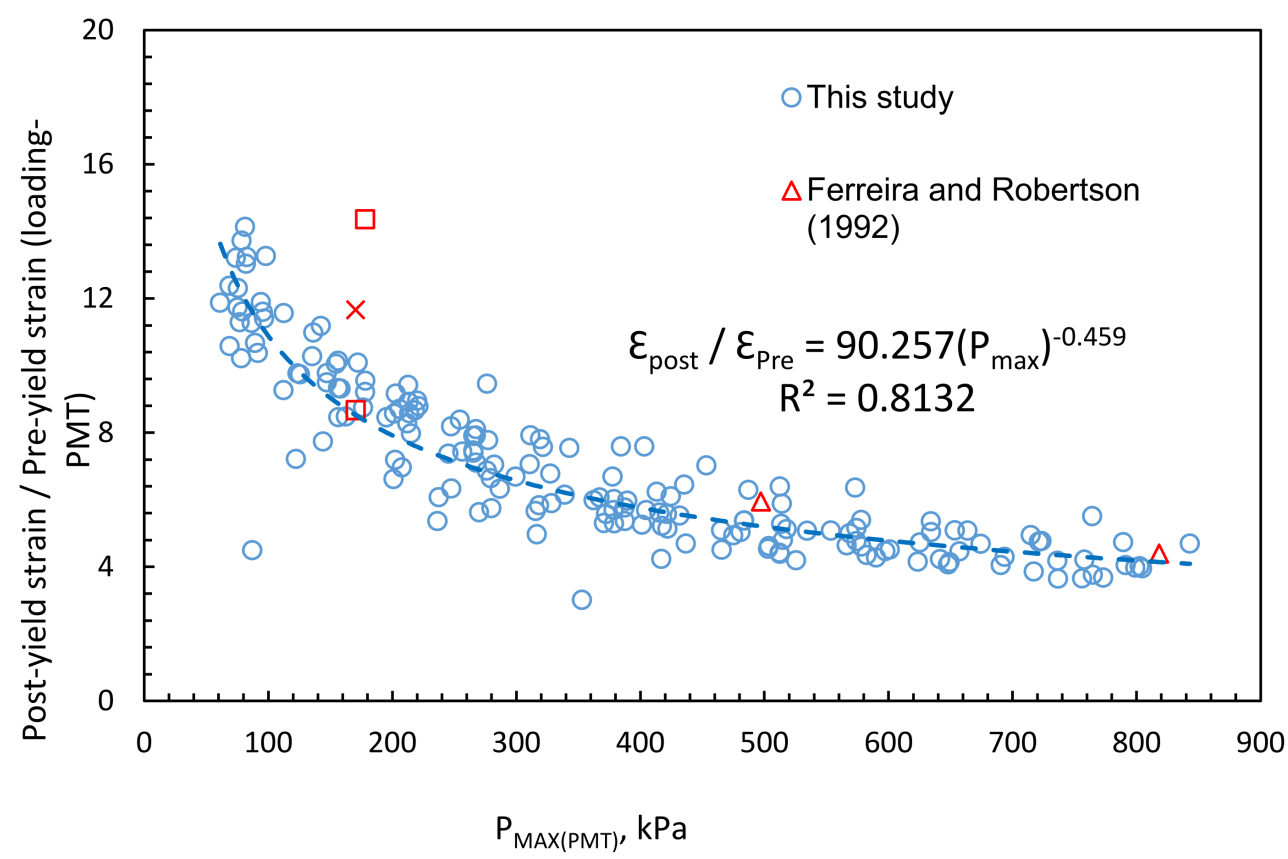

Figure 14. Post-yield/pre-yield strain versus maximum pressure (PMT loading phase). 


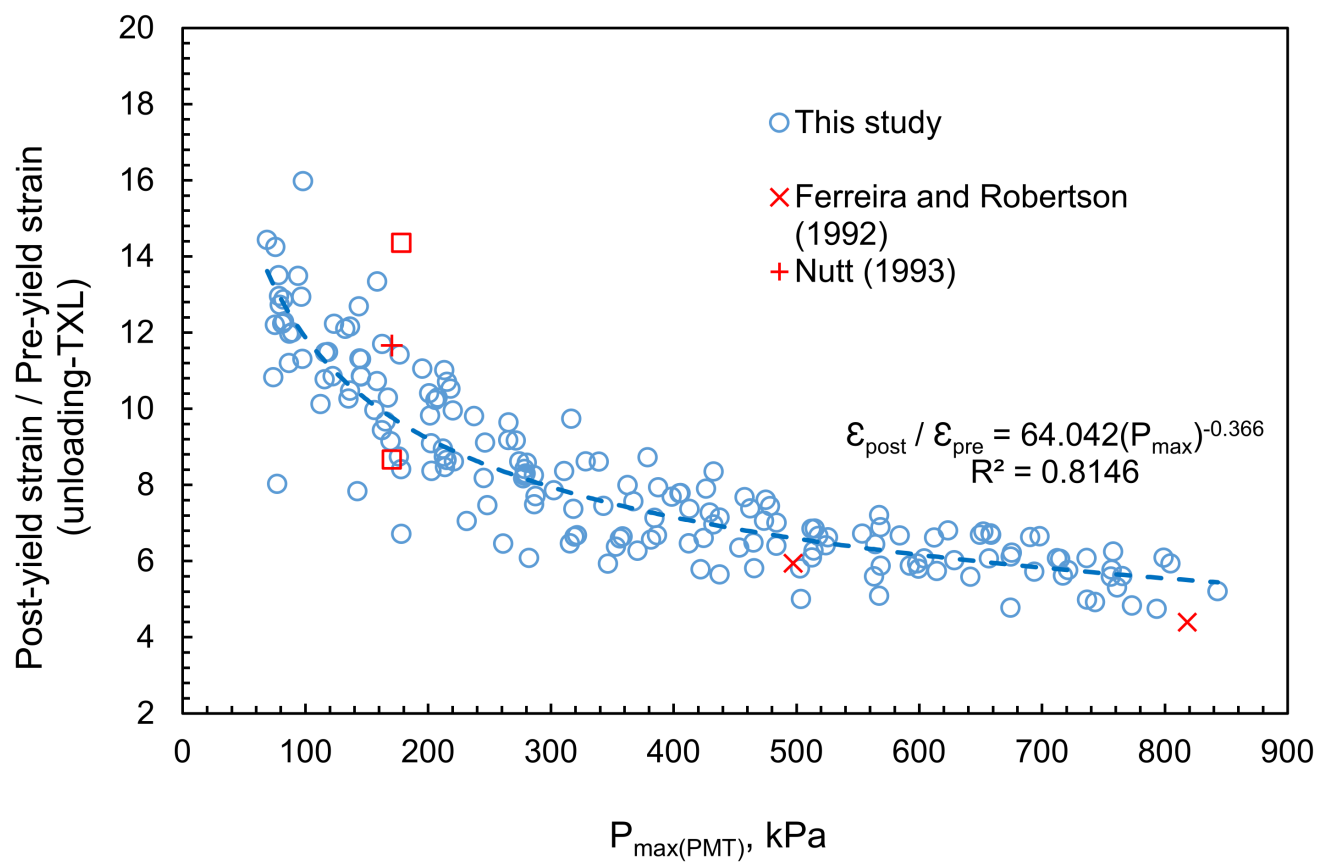

Figure 15. Post-yield/pre-yield strain versus maximum pressure (PMT unloading).

Figures 16 and 17 show the relations of post-yield strain $\left(\varepsilon_{\text {post TXL }} / \sigma_{y}^{\prime}\right)$ versus maximum pressure $\left(\mathrm{P}_{\max }\right)$ for the loading and unloading phases, respectively, for triaxial test curves. It is observed that $\varepsilon_{\text {post TXL }} / \sigma^{\prime}{ }_{\mathrm{y}}$ increases in an exponential pattern after achieving the value of about 0.00075 (loading) and 0.00018 (unloading), corresponding to a $P_{\max }$ value of about $209 \mathrm{kPa}$ (loading) and $203 \mathrm{kPa}$ (unloading), respectively.

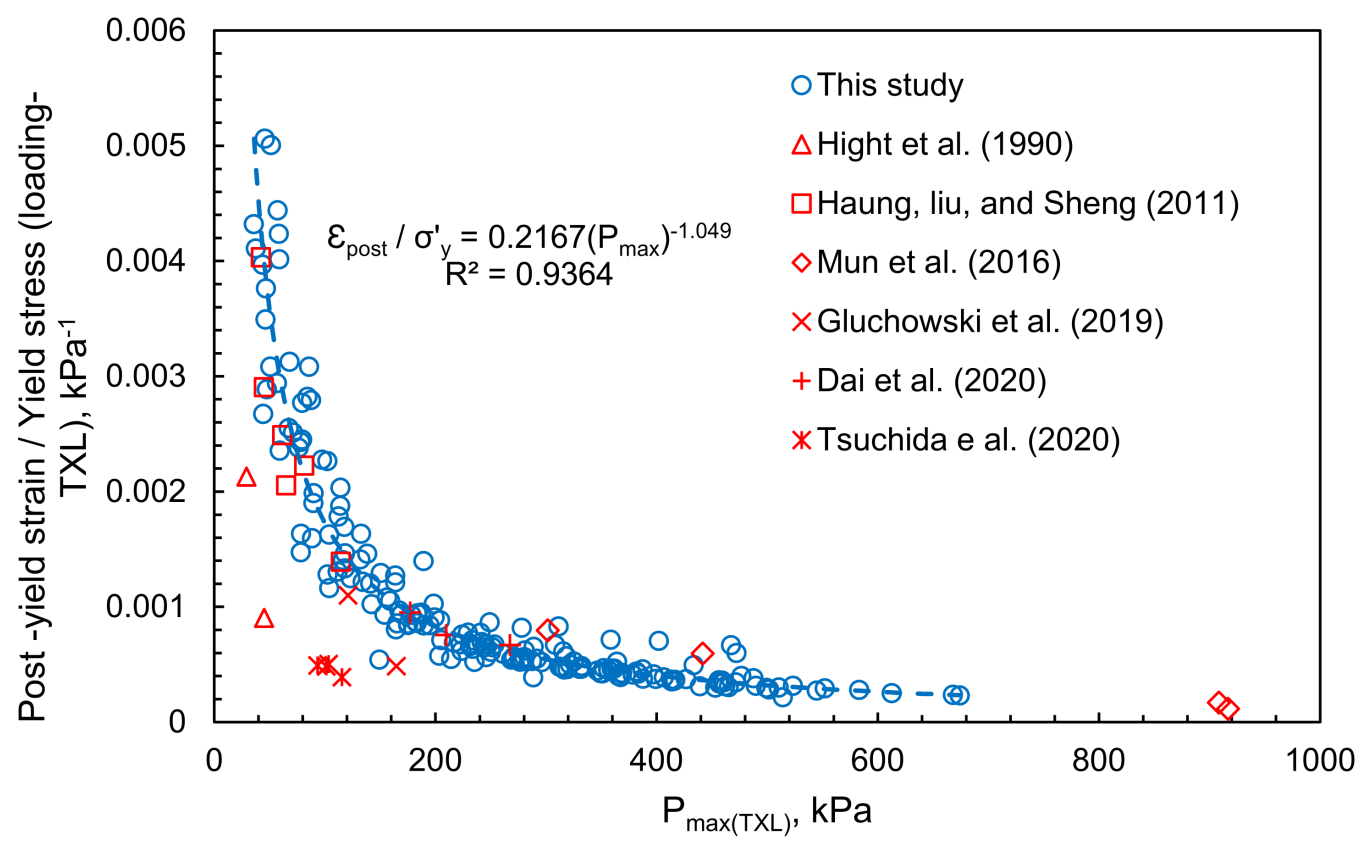

Figure 16. Post-yield strain/yield stress versus maximum pressure (TXL loading phase). 


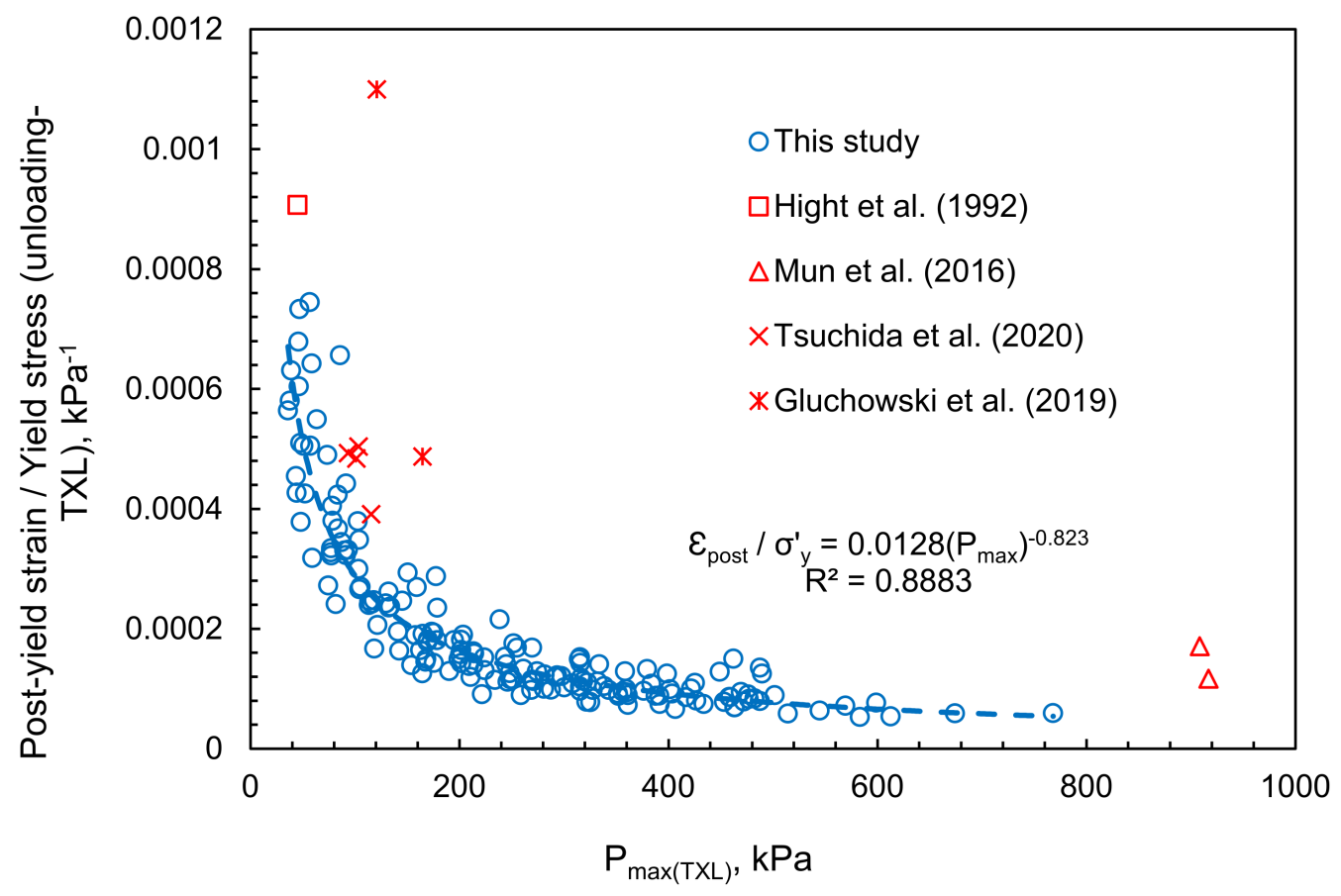

Figure 17. Post-yield strain/yield stress versus maximum pressure (TXL unloading phase).

Figures 18 and 19 show the loading and unloading phases, respectively, of triaxial test curves. Here, the $\varepsilon_{\text {post (TXL) }} / \varepsilon_{\text {pre (TXL) }}$ starts rising exponentially after attaining values of about 5.25 (loading) and 6.3 (unloading), which correspond to the $\mathrm{P}_{\max }$ values of $209 \mathrm{kPa}$ (loading) and $213 \mathrm{kPa}$ (unloading), respectively. The data in Figures 16-19 are congruent to the welldocumented past studies on the loading phase of triaxial tests conducted on clays (Table 3).

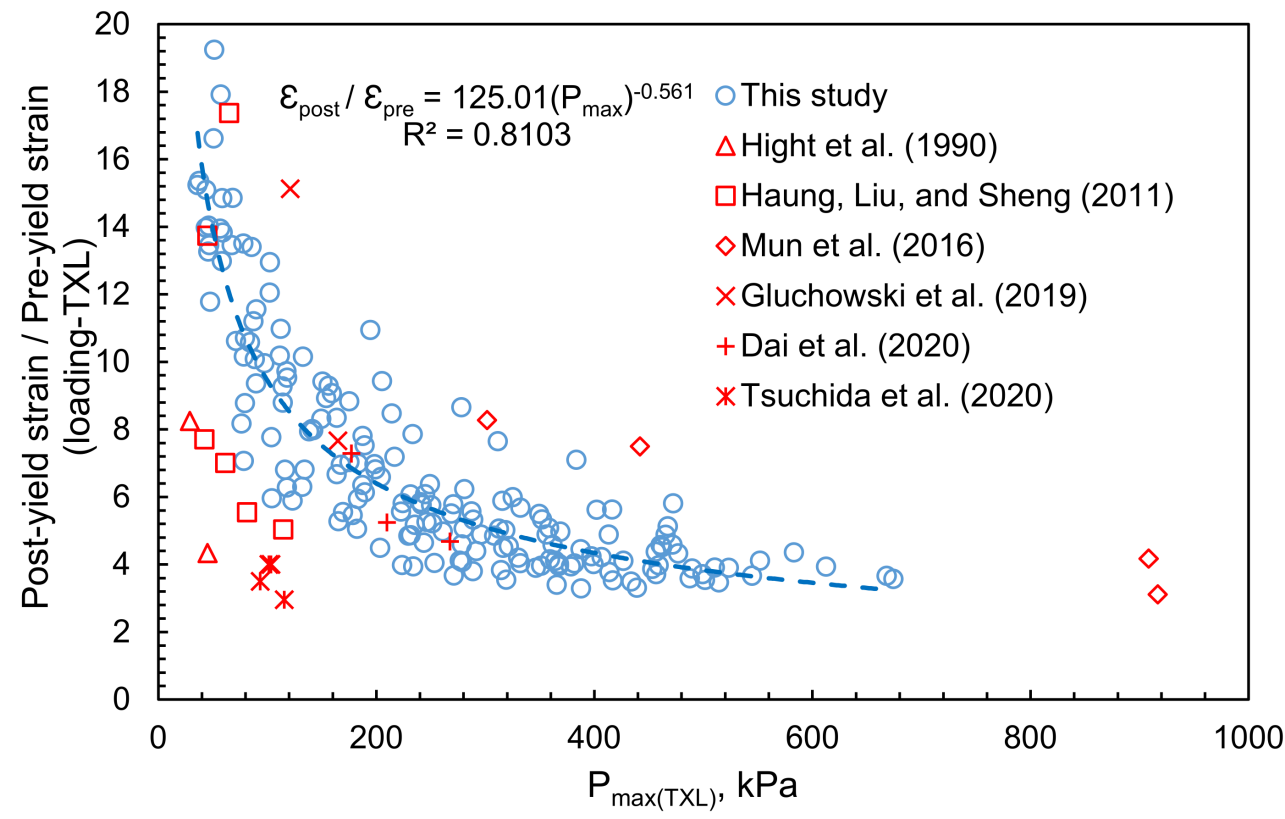

Figure 18. Post-yield/pre-yield strain versus maximum pressure (TXL loading phase). 


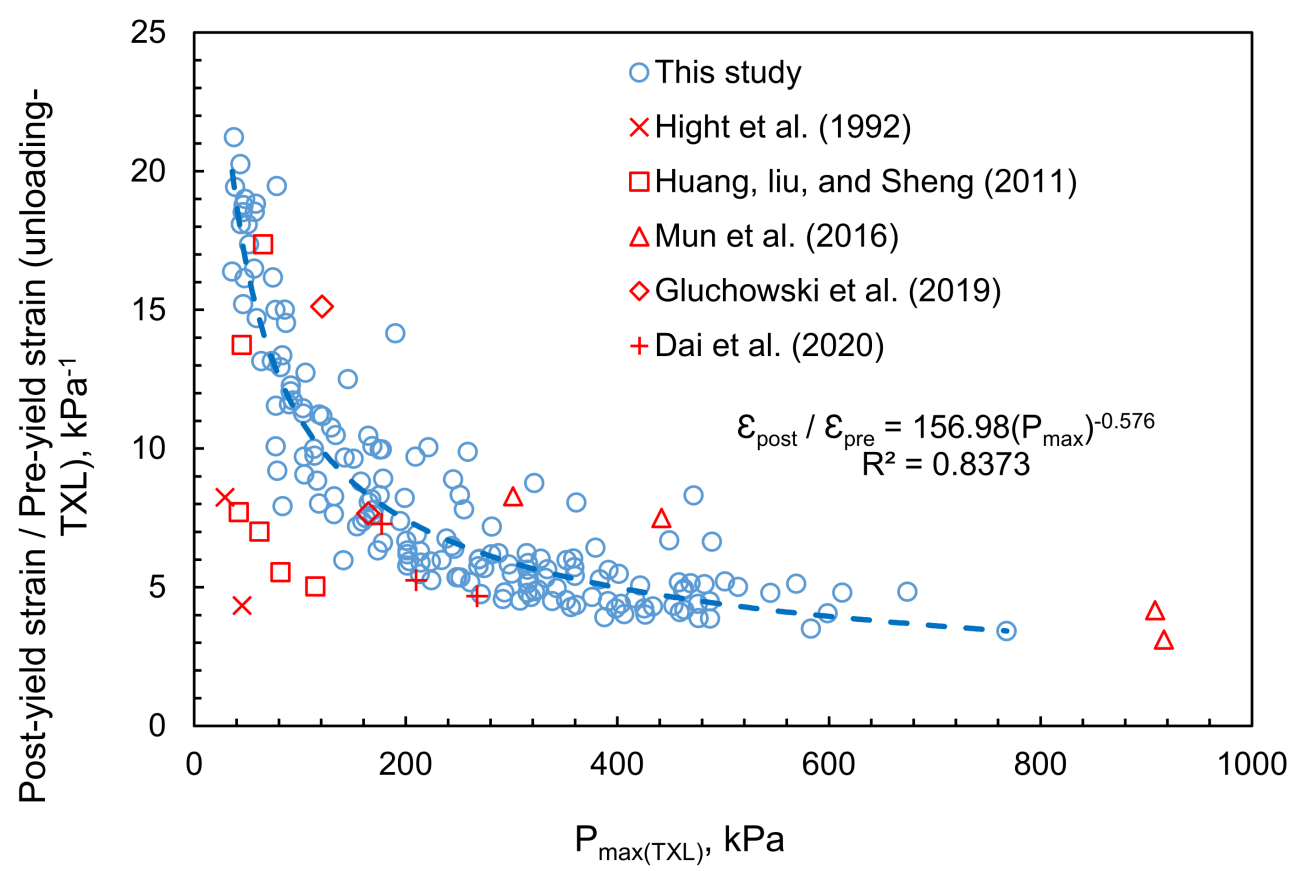

Figure 19. Post-yield/pre-yield strain versus maximum pressure (TXL unloading phase).

Figures 20 and 21 present the relations of post-yield strain/yield stress (i.e., $\varepsilon_{\text {post }(\mathrm{CRS})} / \sigma_{\mathrm{y}}^{\prime}$ ) versus maximum pressure $\left(\mathrm{P}_{\max }\right)$ for the loading and unloading phases of CRS tests. It is observed that the $\varepsilon_{\text {post (CRS) }} / \sigma_{\text {y }}^{\prime}$ increases rapidly after reaching about 0.001 (loading) and 0.001 (unloading), corresponding to the $\mathrm{P}_{\max }$ values of about $217 \mathrm{kPa}$ (loading) and $210 \mathrm{kPa}$ (unloading), respectively.

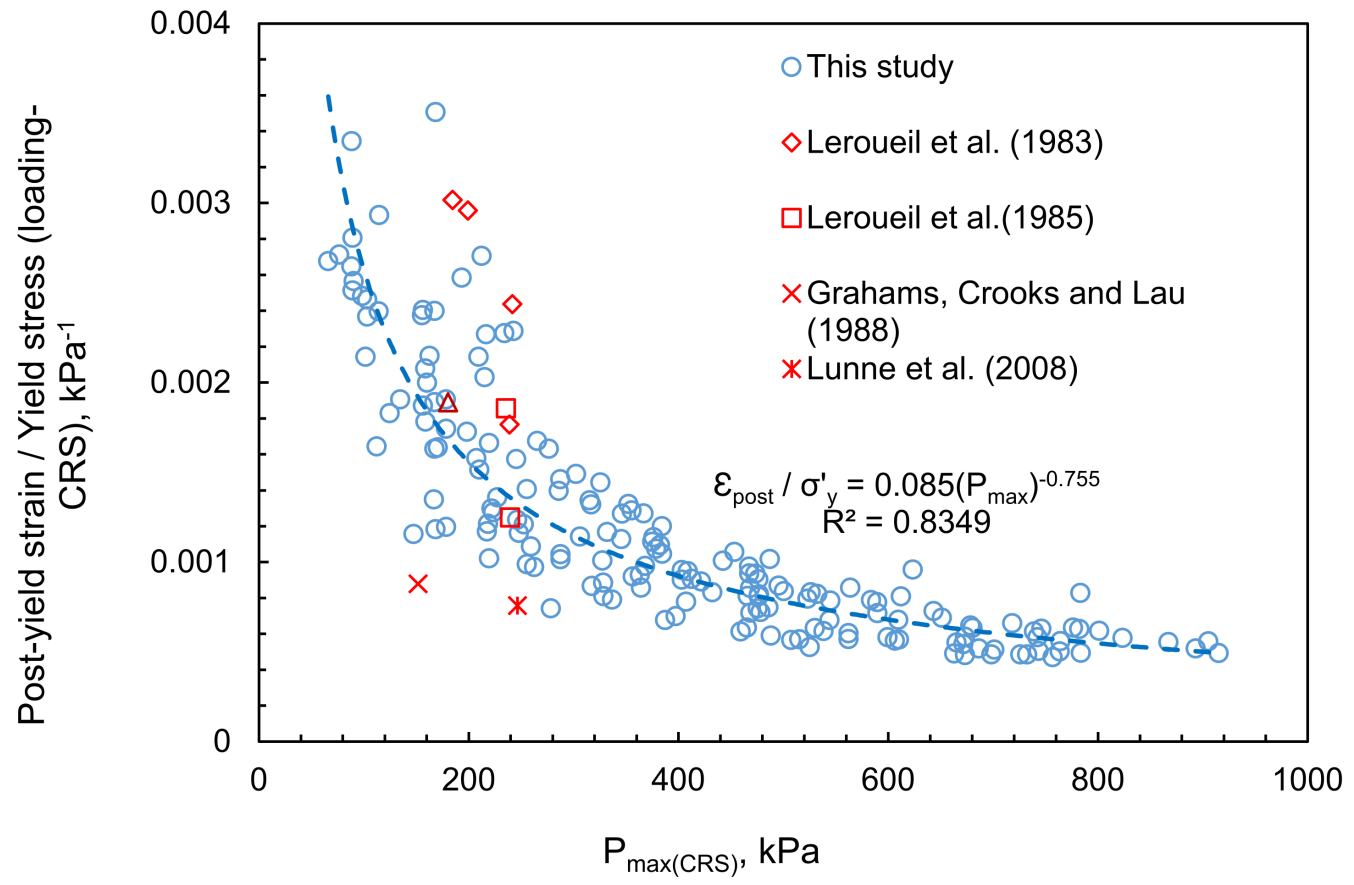

Figure 20. Post-yield strain/yield stress versus maximum pressure (CRS loading phase). 


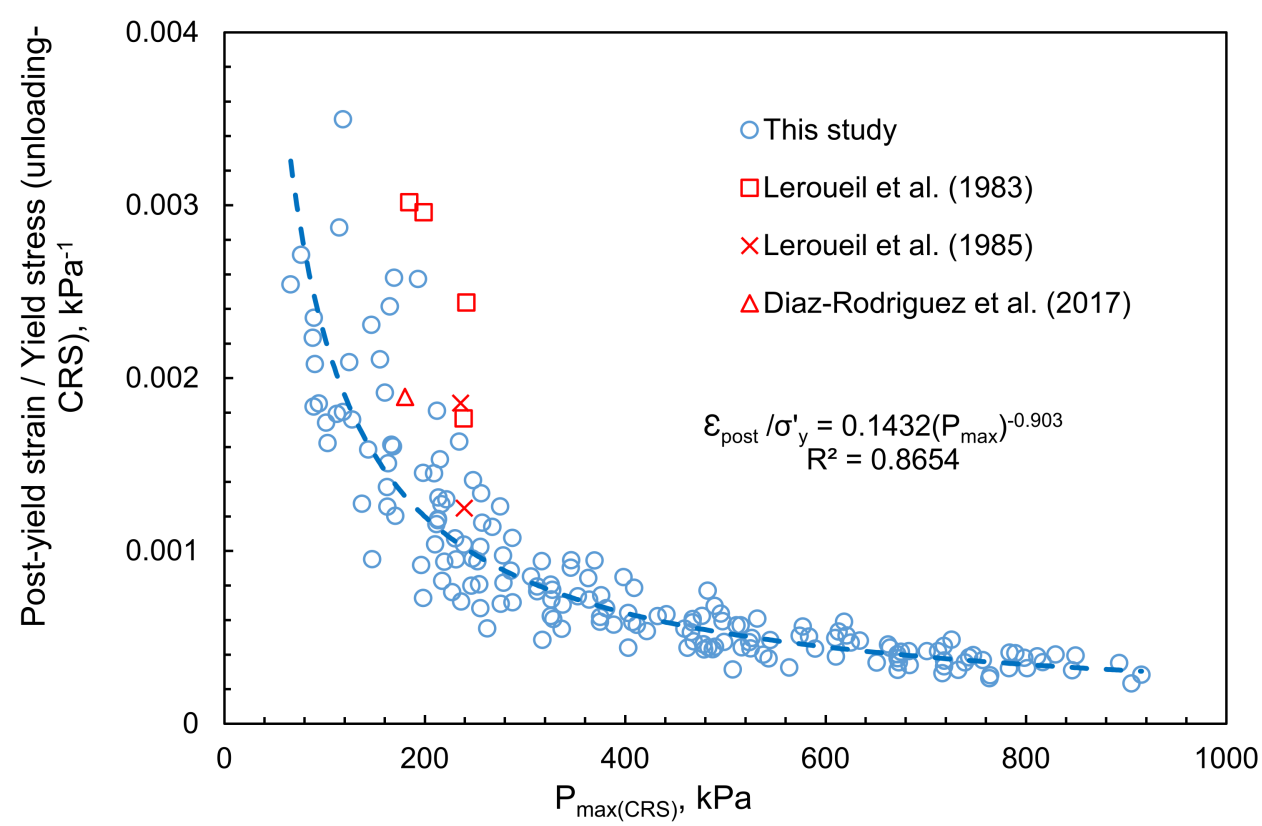

Figure 21. Post-yield strain/yield stress versus maximum pressure (CRS unloading phase).

Figures 22 and 23 show that the $\varepsilon_{\text {post (CRS) }} / \varepsilon_{\text {pre (CRS) }}$ also rises rapidly after starting from about 5.2 (loading) and 5.8 (unloading), which correspond to the $P_{\max }$ values of $219 \mathrm{kPa}$ (loading) and $217 \mathrm{kPa}$ (unloading), respectively. The data in Figures 20-23 correspond to previous studies for the loading phase of CRS tests conducted on clays (Table 4). Figure 22 shows the scattered data up to $300 \mathrm{kPa}$ maximum pressure $\left(\mathrm{P}_{\max }\right)$ due disturbance in the compression phase for very soft to soft nature of soil, whereas Figure 23 shows more consistent results in the unloading phase.

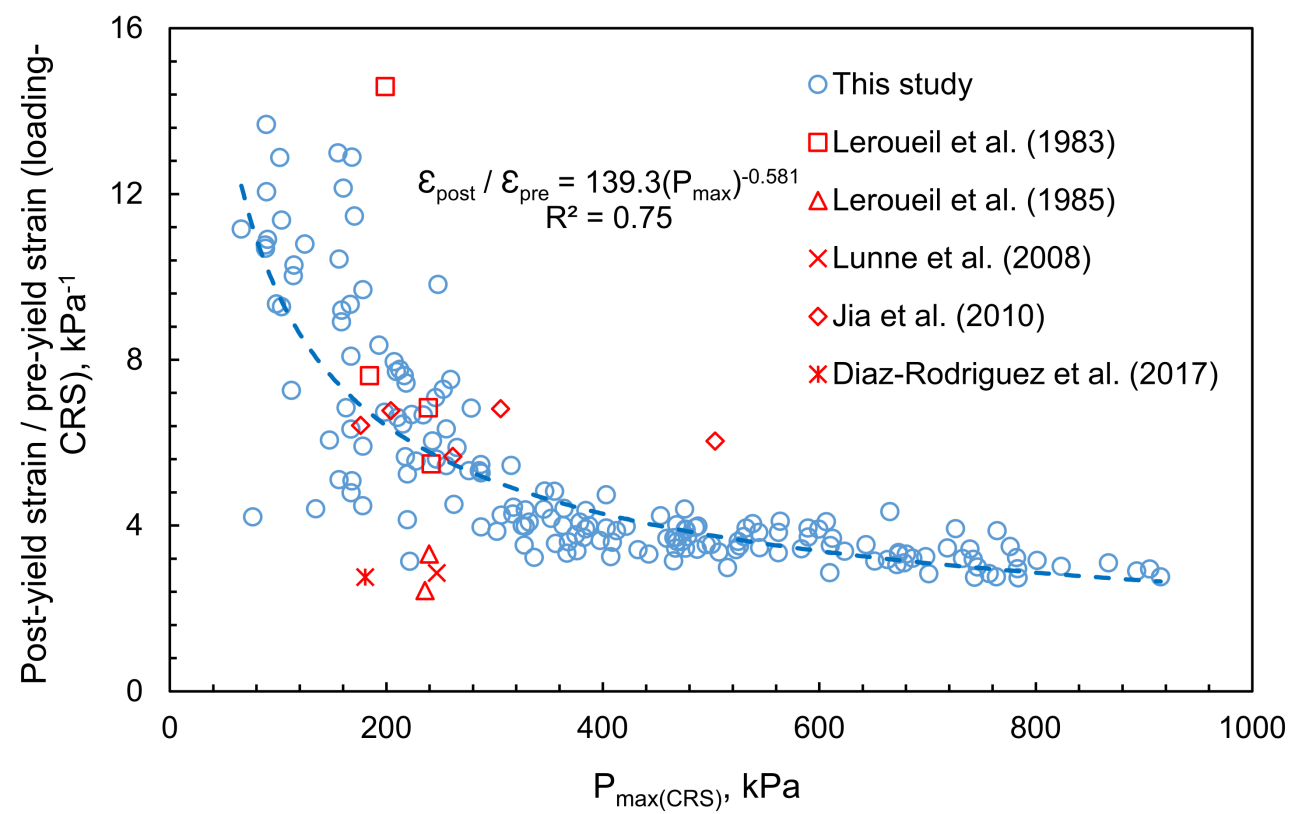

Figure 22. Post-yield/pre-yield strain versus maximum pressure ( $\left.\mathrm{P}_{\max }\right)$ (CRS loading phase). 


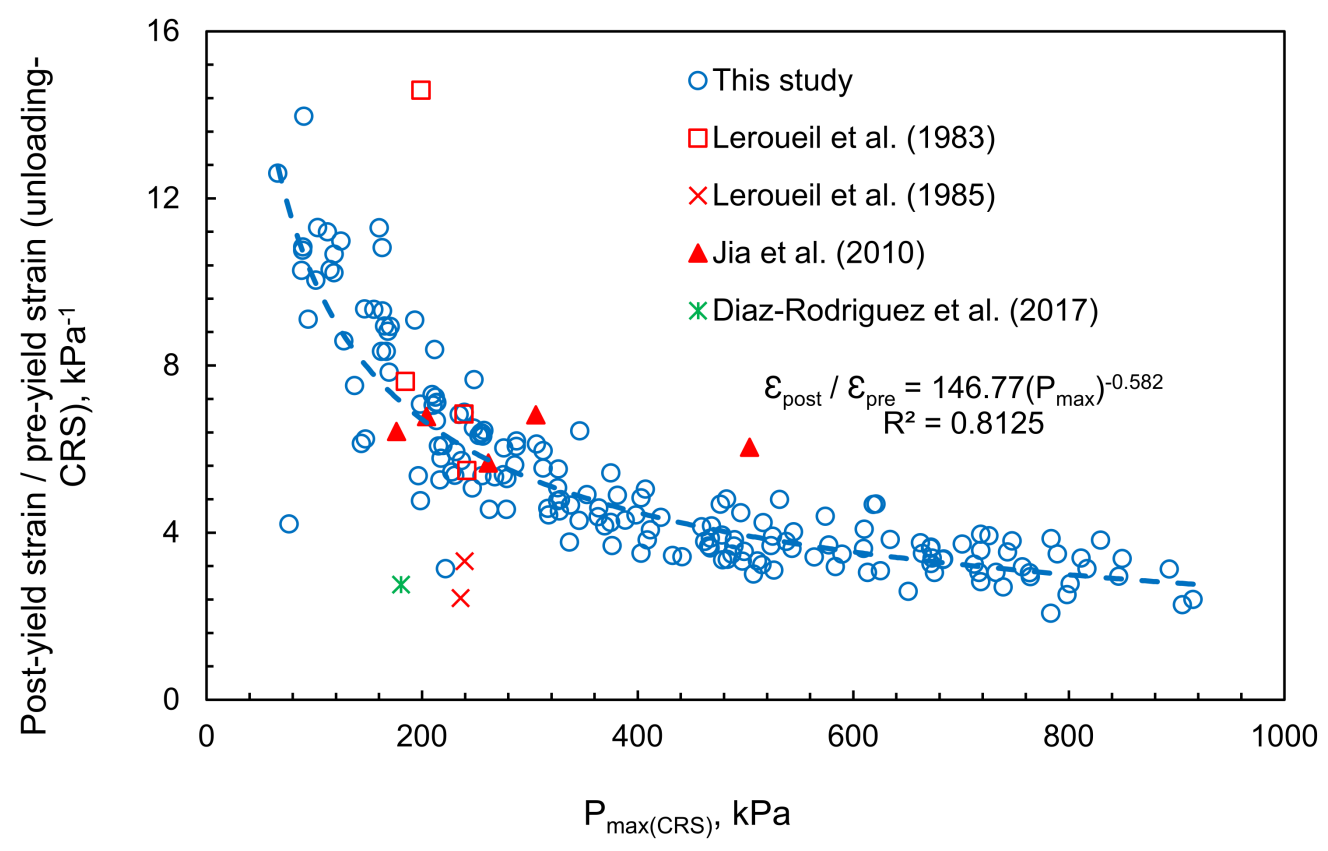

Figure 23. Post-yield/pre-yield strain versus maximum pressure ( $\left.\mathrm{P}_{\max }\right)(\mathrm{CRS}$ unloading phase).

Figures 12-23 show that the unloading phase of PMT, TXL, and CRS tests generates values of $\left(\varepsilon_{\text {post }} / \sigma_{y}^{\prime}\right)$ and $\left(\varepsilon_{\text {post }} / \varepsilon_{\text {pre }}\right)$ close to those determined from the loading phase. Furthermore, the initiation of an exponential rise in the post-yield strain was observed at the $\mathrm{P}_{\max }$ value, starting from $100 \mathrm{kPa}$ for soft clay, and then increased for the upper layer of very soft clay which failed even at $P_{\max }$ of $36 \mathrm{kPa}$ due to the high moisture content and very low dry density near ground surface. The range of $36 \mathrm{kPa}$ to $100 \mathrm{kPa}$ is equivalent to overburden pressure of embankment height of about $2 \mathrm{~m}$ to $5 \mathrm{~m}$ which is congruent to the range of vertical overburden pressure of most of the embankment failure cases presented in Table 1. It also shows the precision and closeness of the $P_{\max }$ values determined from different tests, such as PMT, TXL and CRS tests used in this research.

It is observed from Figures $14,15,18,19,22$ and 23 that the post-yield strains $\left(\varepsilon_{\text {post }}\right)$ are 3 to $14,3.3$ to 19.2 , and 2.7 to 13.7 times higher in the loading phase and 4.7 to $15.9,3.4$ to 21 , and 2 to 14 times higher in the unloading phase when compared with the pre-yield strains $\left(\varepsilon_{\text {pre }}\right)$ for PMT, TXL, and CRS tests, respectively.

Figure 24 presents the predicted chart showing the relation of post-yield strain/yield stress $\left(\varepsilon_{\text {post }} / \sigma_{y}^{\prime}\right)$ versus $P_{\max }$ for PMT, TXL, and CRS tests shown collectively. At a glance, it is observed that the ratio ' $\varepsilon_{\text {post }} / \sigma^{\prime}$ ' increases for soft clays even at low $P_{\max }$ for all the PMT, TXL, and CRS tests. Hence, for a specific value of $\varepsilon_{\text {post }} / \sigma^{\prime}{ }_{y}, P_{\max }$ can be predicted for a wide range of soil stiffness, i.e., very soft to very stiff clays. If the yield stress ' $\sigma^{\prime}{ }_{y}$ ' for the embankment is determined from any of PMT, TXL, and CRS tests, and $P_{\max }$ (maximum overburden stress) is known, then a critical and significant parameter, i.e., a post-yield strain $\left(\varepsilon_{\text {post }}\right)$, can be estimated to manage the expected damage for embankment failure to save money and avoid life-threatening situations. In these situations, the failure of embankment can be averted by stopping the construction of embankment at or before the predicted value of $P_{\max }$ (i.e., a maximum overburden stress for the maximum height of embankment). 


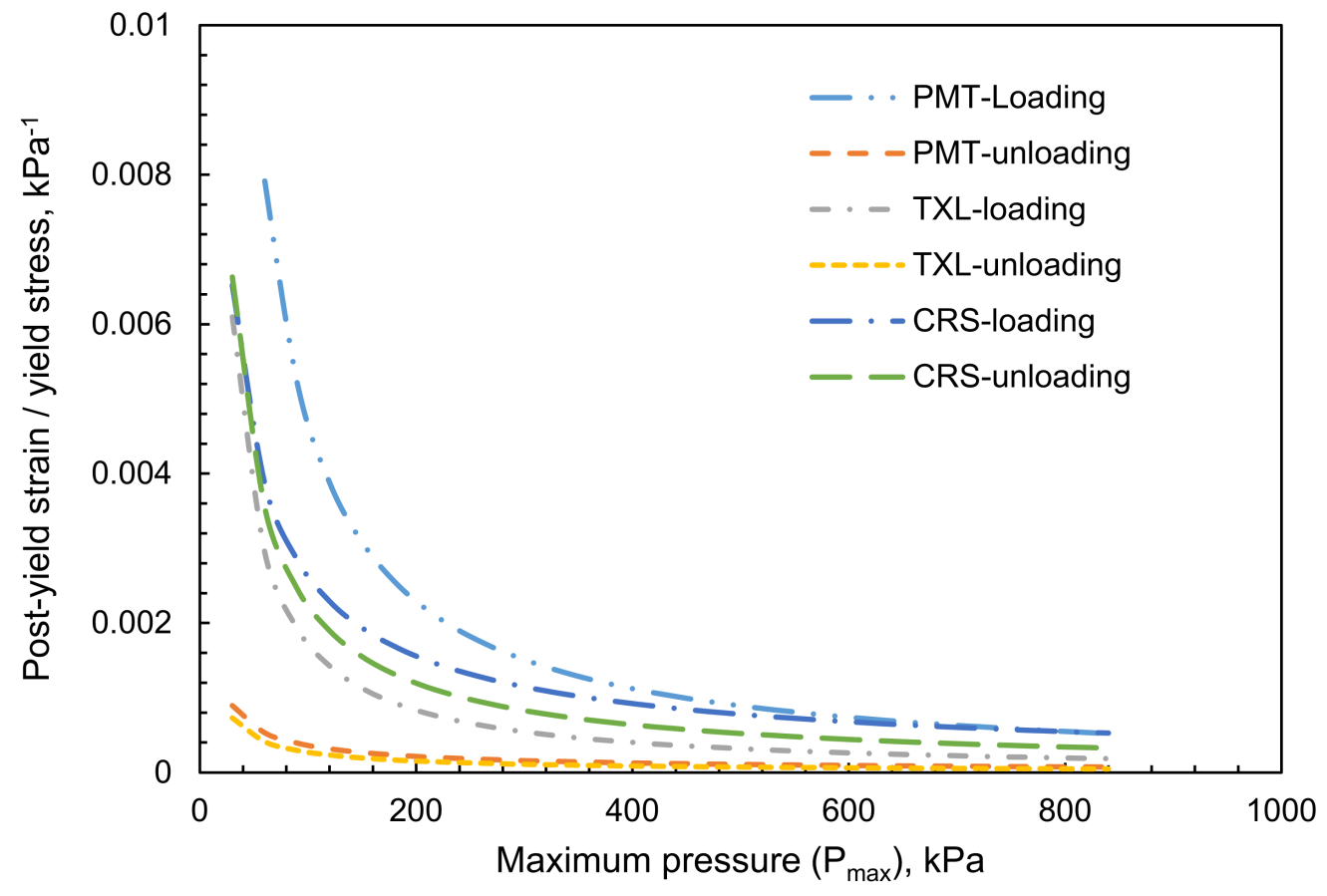

Figure 24. Post-yield strain/yield stress for PMT, TXL, and CRS (loading and unloading phases).

Figure 25 presents the predicted collective curves which show post-yield strain/preyield strain trends $\left(\varepsilon_{\text {post }} / \varepsilon_{\text {pre }}\right)$ versus $P_{\max }$ for PMT, TXL, and CRS for the loading and unloading phases. These curves are significant in the way that, on the ground, embankments may provide pre-yield strain which can initiate exponential post-yield strains. Hence, the proposed chart in Figure 25 shows that by using $\varepsilon_{\text {pre }}$ and $P_{\max }$, the pot-yield strain $\left(\varepsilon_{\text {post }}\right)$ can be determined for the embankments in very soft, soft, stiff, and very stiff saturated clays. The zone of exponential post-yield strain is also shown in Figure 25 where the post-yield strain increases rapidly from a $\varepsilon_{\text {post }} / \varepsilon_{\text {pre value of }} 10$ to 11 at an applied pressure of $36 \mathrm{kPa}$ to100 $\mathrm{kPa}$ for very soft clay to soft clay, respectively.

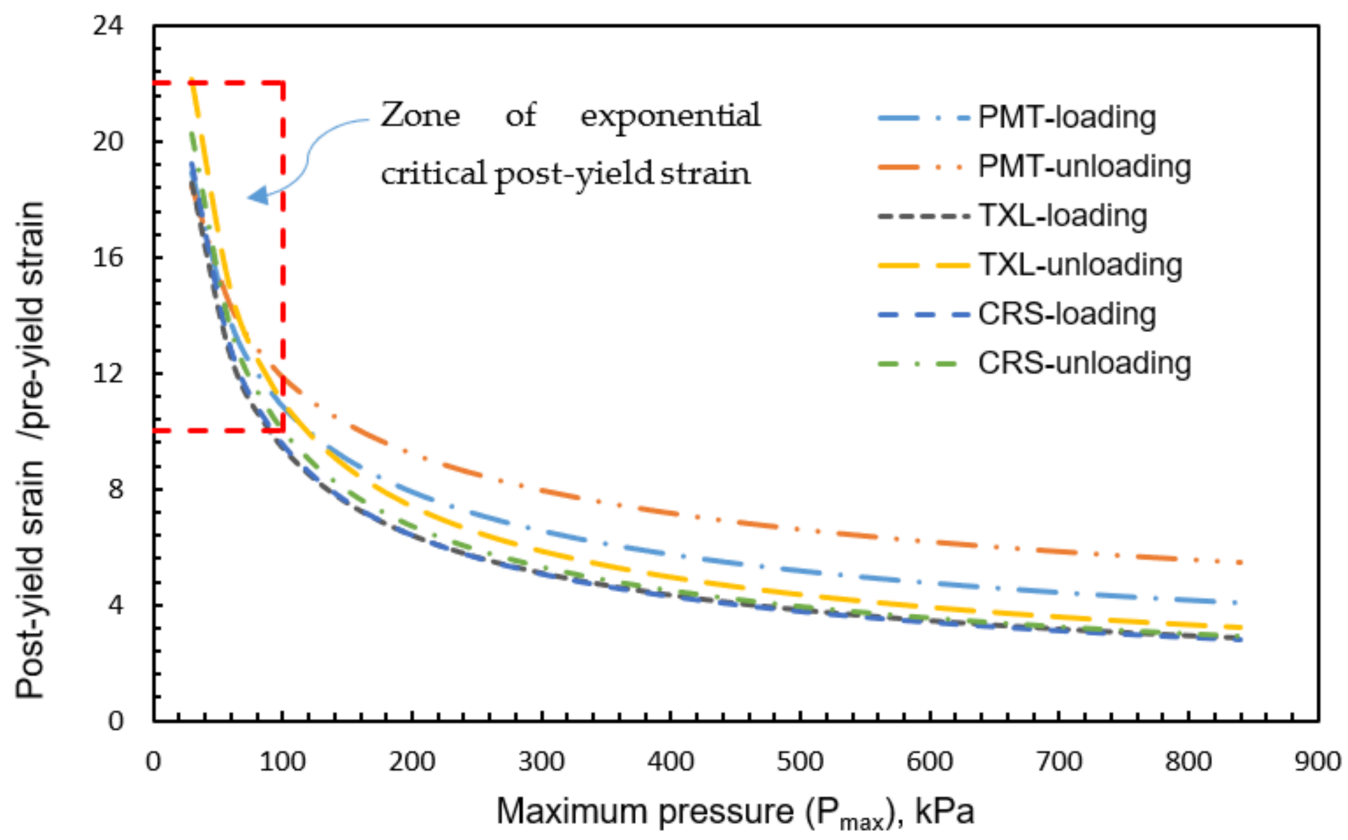

Figure 25. Post-yield/pre-yield strain for PMT, TXL, and CRS (loading and unloading phases). 
The exponential post-yield strain was observed with very soft clay having high moisture content and very low dry density, which caused failure even when low pressure was applied, i.e., $36 \mathrm{kPa}$. Hence, the predictive correlations for the post-yield strain can be applied confidently to embankments with very soft saturated clay, as well as for soft, stiff, and very stiff clays.

It is worth mentioning that the charts in Figures 24 and 25 enable geotechnical engineers to interconvert the laboratory and in situ data for very soft to very stiff saturated clays. The in situ post-yield strains can be estimated by conducting solely triaxial or CRS tests to anticipate the behavior of saturated clay in existing embankments after failure. The yielding behavior observed in PMT, TXL, and CRS tests in the loading and unloading phases is observed to be in a narrow range, in the case of very soft and soft clay, as well as in the case of the ratio of post-yield/pre-yield strain. However, some differences are shown by stiff to very stiff clay (Figure 25). The CRS tests were conducted to evaluate yield stress against triaxial (TXL) and in situ pressuremeter tests (PMT), as mentioned in [11].

The values of pre-yield and post-yield strains are not known in the case of embankment failures; thus, correlation for post-yield strains is very important for the critical study of stability of embankments involving very soft to very stiff saturated clay. The data of past studies are used to validate this research; however, data from previous research was not used in the proposed correlations. Expedient correlations of $\sigma_{y}^{\prime}, \varepsilon_{\text {pre }}, \varepsilon_{\text {post }}$, and $P_{\max }$ in PMT, TXL, and CRS tests for the loading and unloading phases for clays with very soft to very stiff consistency are presented in Table 5.

Table 5. Proposed correlations for post-yield strain for saturated clay.

\begin{tabular}{|c|c|c|c|c|c|}
\hline Sr. No. & Proposed Correlation & Parameters & $\mathbf{R}^{2}$ & Test & Loading/Unloading \\
\hline 1 & $\varepsilon_{\text {post (PMT) }} / \sigma_{y=}^{\prime} 0.537\left(\mathrm{P}_{\max }\right)^{-1.03}$ & $\varepsilon_{\text {post }}, \sigma_{y}^{\prime}, P_{\max }$ & 0.946 & PMT & Loading \\
\hline 2 & $\varepsilon_{\text {post (PMT) }} / \sigma_{y=0}^{\prime} 0.011\left(\mathrm{P}_{\max }\right)^{-0.751}$ & $\varepsilon_{\text {post }}, \sigma_{y}^{\prime}, P_{\max }$ & 0.847 & PMT & Unloading \\
\hline 3 & $\mathcal{E}_{\text {post (PMT) }} / \mathcal{E}_{\text {pre (PMT) }}=90.2\left(\mathrm{P}_{\max }\right)^{-0.459}$ & $\varepsilon_{\text {post }}, \varepsilon_{\text {pre }}, P_{\max }$ & 0.813 & PMT & Loading \\
\hline 4 & $\varepsilon_{\text {post (PMT) }} / \varepsilon_{\text {pre (PMT) }}=64.0\left(\mathrm{P}_{\max }\right)^{-0.366}$ & $\varepsilon_{\text {post }}, \mathcal{E}_{\text {pre }}, P_{\max }$ & 0.814 & PMT & Unloading \\
\hline 5 & $\mathcal{E}_{\text {post (TXL) }} / \sigma_{\mathrm{y}}^{\prime}=0.216\left(\mathrm{P}_{\max }\right)^{-1.049}$ & $\varepsilon_{\text {post }}, \sigma_{y}^{\prime}, P_{\max }$ & 0.936 & TXL & Loading \\
\hline 6 & $\mathcal{E}_{\text {post (TXL) }} / \sigma_{\mathrm{y}}^{\prime}=0.012\left(\mathrm{P}_{\max }\right)^{-0.823}$ & $\varepsilon_{\text {post }}, \sigma_{y}^{\prime}, P_{\max }$ & 0.888 & TXL & Unloading \\
\hline 7 & $\mathcal{E}_{\text {post (TXL) }} / \mathcal{E}_{\text {pre (TXL) }}=125\left(\mathrm{P}_{\max }\right)^{-0.561}$ & $\mathcal{E}_{\text {post }}, \mathcal{E}_{\text {pre }}, P_{\max }$ & 0.810 & TXL & Loading \\
\hline 8 & $\varepsilon_{\text {post (TXL) }} / \varepsilon_{\text {pre }(\mathrm{TXL})}=156\left(\mathrm{P}_{\max }\right)^{-0.576}$ & $\varepsilon_{\text {post }}, \varepsilon_{\text {pre }}, P_{\max }$ & 0.785 & TXL & Unloading \\
\hline 9 & $\mathcal{E}_{\text {post (CRS) }} / \sigma_{y}^{\prime}=0.085\left(P_{\max }\right)^{-0.755}$ & $\varepsilon_{\text {post }}, \sigma_{y}^{\prime}, P_{\max }$ & 0.834 & CRS & Loading \\
\hline 10 & $\mathcal{E}_{\text {post }(\mathrm{CRS})} / \sigma_{\mathrm{y}}^{\prime}=0.143\left(\mathrm{P}_{\max }\right)^{-0.903}$ & $\varepsilon_{\text {post }}, \sigma_{y}^{\prime}, P_{\max }$ & 0.865 & CRS & Unloading \\
\hline 11 & $\mathcal{E}_{\text {post (CRS) }} / \mathcal{E}_{\text {pre (CRS) }}=139.3\left(\mathrm{P}_{\max }\right)^{-0.581}$ & $\mathcal{E}_{\text {post }}, \mathcal{E}_{\text {pre }}, \mathrm{P}_{\max }$ & 0.750 & CRS & Loading \\
\hline 12 & $\varepsilon_{\text {post (CRS) }} / \mathcal{E}_{\text {pre (CRS) }}=146.7\left(\mathrm{P}_{\max }\right)^{-0.582}$ & $\varepsilon_{\text {post }}, \varepsilon_{\text {pre }}, P_{\max }$ & 0.812 & CRS & Unloading \\
\hline
\end{tabular}

PMT = pressuremeter; TXL = triaxial; $\mathrm{CRS}=$ constant-rate-of-strain consolidation.

A regression index for proposed correlations is reasonable for PMT, TXL, and CRS tests. The yield stress $\left(\sigma_{y}^{\prime}\right)$ is the initial point and the $P_{\max }$ is the last point of the stressstrain travel for post-yield strain; hence, both the stresses play a key role in the failure phenomenon of soft clay in embankments. This study shows that $\varepsilon_{\text {pre }}$ and $\varepsilon_{\text {post }}$ evaluated from the unloading phase of clay are equally precise, as observed in the loading phase. Charts are developed to serve the inter-conversion of in situ and laboratory test results for expedient evaluation of in situ post-yield strains $\left(\varepsilon_{\text {post }}\right)$ for embankments comprising saturated clay, especially very soft to soft clay.

An individual site comprising lean clay with a range of PI from 28 to 38, dry density from $1.362 \mathrm{~g} / \mathrm{cm}^{3}$ to $1.675 \mathrm{~g} / \mathrm{cm}^{3}$, and MC from $26 \%$ to $38 \%$ was investigated by PMT, TXL, and CRS tests. Six boreholes were drilled to retrieve undisturbed samples (UDS). Prebored in situ PMTs were performed at six points. It was observed that the GWT of a separate site was stable at $11.2 \mathrm{~m}$. The soil strata were found to be very soft to very stiff.

The results from Figures 12-23 show that for the pressure level $\mathrm{P}_{\max }<300 \mathrm{kPa}$, the data are distributed in a wider range; thus, there was lower accuracy (i.e., lower $\mathrm{R}^{2}$ ) in this zone, i.e., in a zone up to $5 \mathrm{~m}$ deep, which comprises very soft clay to soft clay. These strata are considered to be critical in sample extrusion, in sample preparation, and in the loading stage; hence, they are prone to some disturbance, showing scattered values of resulting strains which lowers the $\mathrm{R}^{2}$ value in the zone of very soft to soft clay. 
The proposed empirical equations can only be used for approximation of post-yield strain for prior to embankment failure and to take precautions to avoid damages of a post-failure situation. These equations are presented for very soft to very stiff range of clay; hence, the $\mathrm{R}^{2}$ values are less. These equations have limitation to the precise design of embankment for which specific testing program on site and laboratory is required for specific consistency of soil i.e., very soft, soft, stiff, or very stiff.

The application of the zone of critical post-yield strain $\left(\varepsilon_{\text {post }}\right)$ will help to augment the existing knowledge of failure of embankments constructed on very soft to soft clay strata. It will also help to achieve sustainable and long-lasting design, durable/sustainable construction of embankments, and a major reduction in embankment failures due to preemptive measures taken by using the zone of critical strain. The proposed equations can be used for the approximation of post-yield failure strain of clays with a plasticity index (PI) ranging from $19 \%$ to $31 \%$.

The PI level affects the undrained shear strength of clays significantly [84]. The results of this study shown in Figures 12-23 are validated by previous studies mentioned in Tables 1-4. The past research selected for the validation covers the plasticity index (PI) of the clay investigated in this study. Ref [85] described that the increase in plasticity index (PI) causes an increase in the shear strength of clay. Ref [86] argued that the undrained shear strength of clay decreases with an increase in the initial moisture content. In the present study, the strata with a high plasticity index (PI), i.e., from NSL to $2 \mathrm{~m}$ depth, showed lower strength due to high moisture content, as observed in soil samples recovered from field, as the governing factor for the shear strength of clays is the moisture content. For the same level of plasticity, the clays show a low shear strength on high level of moisture content, i.e., soft clays. From NSL to down up to $10 \mathrm{~m}$ depth, the PI is reduced; however, the decrease in moisture content and increase in dry density caused an increase in the shear strength of soil. Hence, this study showed effect of PI in combination with filed moisture and dry density. The proposed correlations can be used for the clays of a specific range of PI investigated in this research.

The anisotropic stress state of soil was determined by the use of a pressuremeter, by evaluating horizontal stress alongside the expansion of the membrane and vertical stress from the effective overburden pressure. This anisotropic stress state was used to define the lateral stress to be applied in triaxial tests. This aspect is mentioned in [85].

The soil consistency classification mentioned in Figure 4 for the clay investigated in this research is based on a description in [87]. Hence, this study can be used for very soft to very stiff clays to design and construct embankments. It is worth mentioning that the post-yield strain can also be an issue, causing failure of natural slopes across many railways and roadways, as reported in site investigation by [88].

Figures 26 and 27 show the measured versus predicted data sets of $\varepsilon_{\text {post }} / \sigma^{\prime}{ }_{\mathrm{y}}$ and $\varepsilon_{\text {post }} / \varepsilon_{\text {pre, }}$ respectively, for PMT, TXL, and CRS tests, which validate the data of this research. The measured versus predicted data sets fall within a line of equality of $\pm 10 \%$. The cost-effective and prompt prediction of post-yield strains suggests that the geotechnical community are required to carry out stability analysis of embankments on very soft to soft clays. The analysis of soft clay strata is a hot issue in relation to sustainable embankment design [89-91]. 


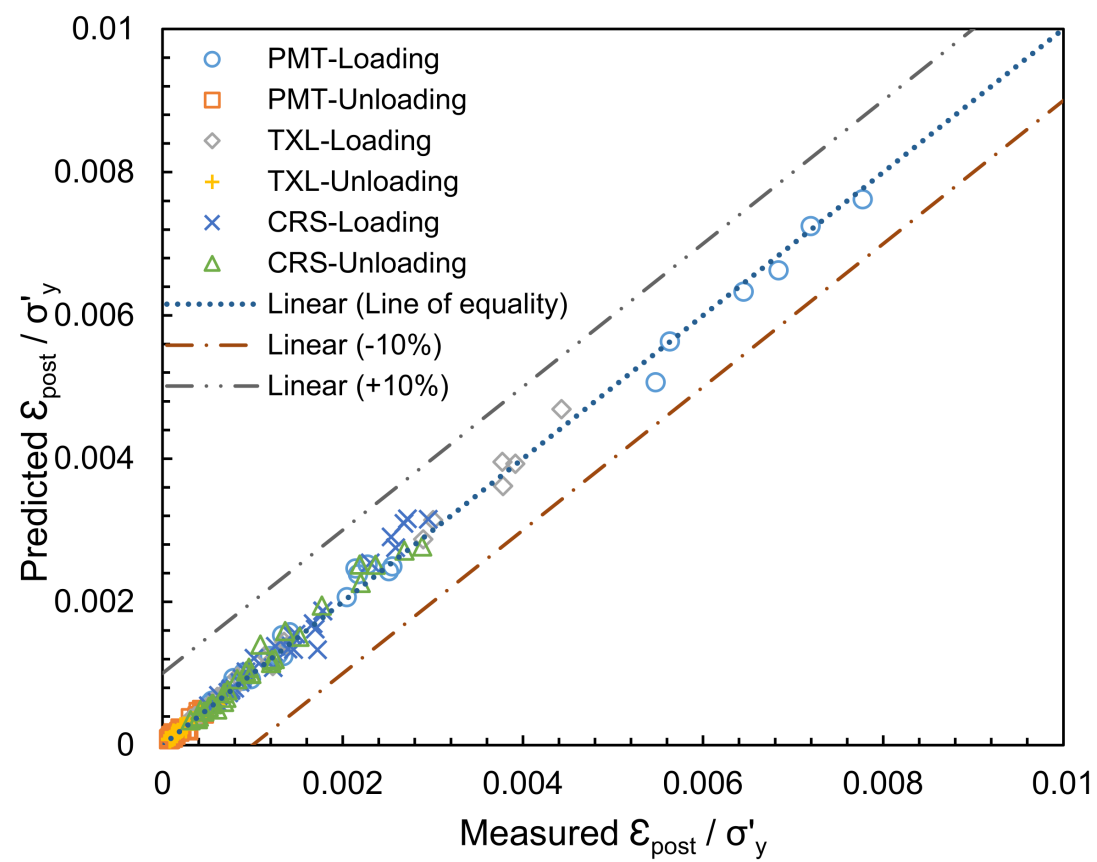

Figure 26. Measured versus predicted post-yield strain/yield stress for PMT, TXL, and CRS (loading and unloading phases).

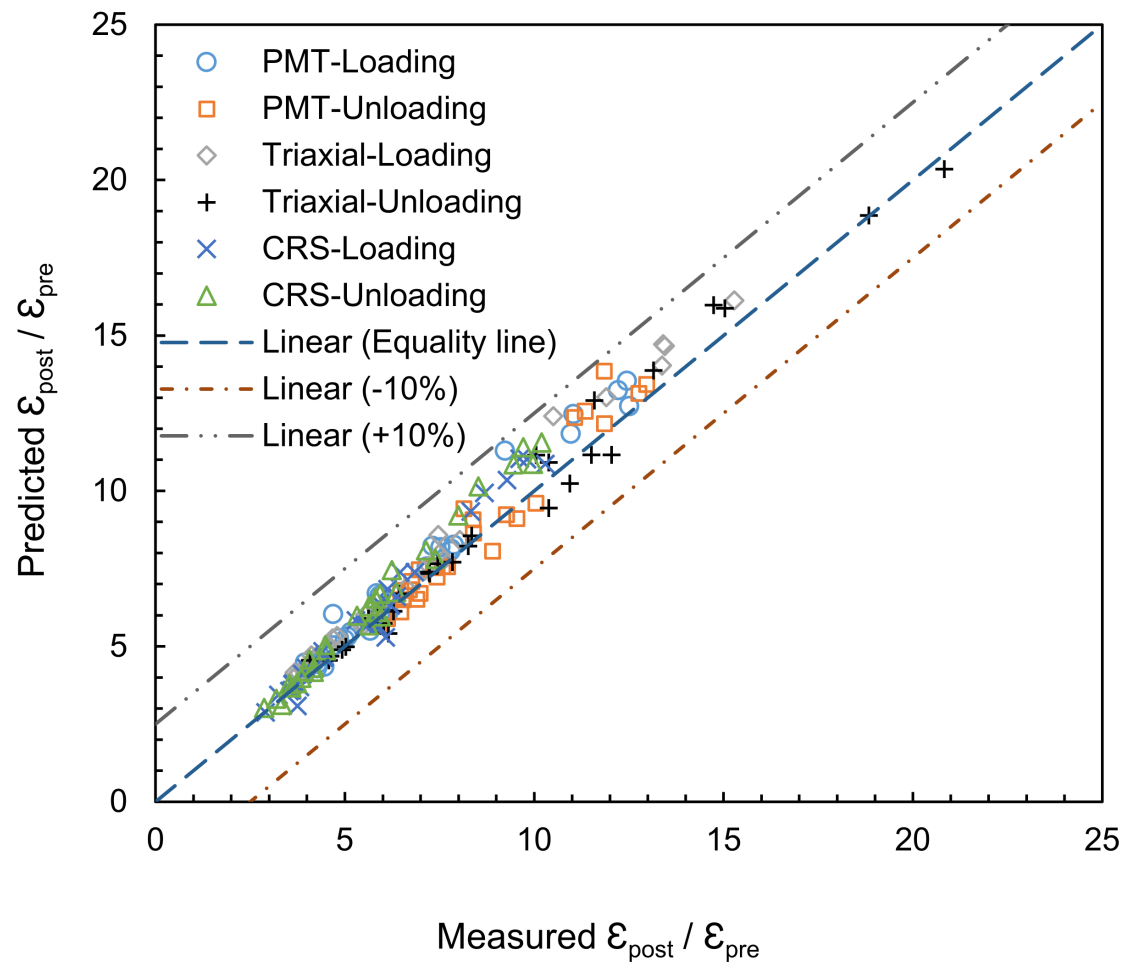

Figure 27. Measured versus predicted post-yield/pre-yield strain for PMT, TXL, and CRS (loading and unloading phases).

\section{Conclusions}

The following conclusions can be drawn from the results and analysis of this study.

(1) Characterization of saturated clay stratum by PMT, TXL, and CRS tests presents that stress-strain curves can be used to evaluate the yield stress $\left(\sigma_{\mathrm{y}}^{\prime}\right)$, the pre-yield strain $\left(\varepsilon_{\text {pre }}\right)$, and the post-yield strain $\left(\varepsilon_{\text {post }}\right)$. This infers that the $\varepsilon_{\text {post }} / \varepsilon_{\text {pre }}$ ranges from 2.7 to 19 in the loading phase and 2 to 21 in the unloading phase. An exponential increase 
in $\varepsilon_{\text {post }} / \varepsilon_{\text {pre }}$ was observed in very soft to soft clay stratigraphy at the values in range of 10 to 21 (a critical range), which is congruent with the range of 4 to 30 found in renowned embankment failure cases of saturated clays worldwide. Application of the critical strain $\left(\varepsilon_{\text {post }}\right)$ zone will help to augment the existing knowledge of failure of embankments constructed on very soft to soft clay strata, and will help to achieve sustainable and long-lasting design and construction of embankments.

(2) This study showed that increase in maximum applied pressure $\left(\mathrm{P}_{\max }\right)$ (which corresponds to height of embankment) causes an increase in the post-yield strain $\left(\varepsilon_{\text {post }}\right)$ in very soft to very stiff clay. This inference can be used for prediction of exponential post-yield strain (leading to embankment failure) by the use of embankment height.

(3) The zone of exponential development of critical post-yield strain was observed for the maximum applied pressure $\left(\mathrm{P}_{\max }\right)$ ranging from $36 \mathrm{kPa}$ to $100 \mathrm{kPa}$, corresponding to very soft and soft clay, respectively. It is worth mentioning that pressure ranging from $36 \mathrm{kPa}$ to $100 \mathrm{kPa}$ corresponds to the approximate embankment height of $3 \mathrm{~m}$ to $5 \mathrm{~m}$, which is observed as a common height in embankment failure cases worldwide.

(4) Simplistic and expedient correlations are proposed for $\varepsilon_{\text {post }} / \sigma_{y}^{\prime}$ and $\varepsilon_{\text {post }} / \varepsilon_{\text {pre }}$ versus $\mathrm{P}_{\max }$ for PMT, TXL, and CRS tests, as the yield stress $\left(\sigma_{\mathrm{y}}^{\prime}\right)$ and the pre-yield strain $\left(\varepsilon_{\text {pre }}\right)$ are precursors of abnormal development of post-yield strain. To benchmark this research, the proposed correlations are validated by past studies on PMT, TXL, and CRS tests for very soft to very stiff saturated clay. Variations in predictions versus the experimental data of an individual site are observed to be within $\pm 10 \%$ of the 1:1 line.

(5) The proposed correlations are developed on the basis of limited test data for a specific soil, i.e., saturated clay. Hence, these correlations may not work well in other soils of different origins and index properties.

\begin{abstract}
Author Contributions: Conceptualization, A.H.K. and Z.u.R.; methodology, A.H.K. and Z.u.R.; software, W.A., A.M.M. and D.M.F.; validation, A.H.K., Z.u.R. and Z.M.; formal analysis, A.H.K., Z.u.R. and W.A.; investigation, A.H.K., Z.u.R.; resources, A.H.K., Z.u.R., W.A., Z.M., A.M.M., D.M.F., M.A. and S.A.; data curation, A.H.K., Z.u.R., W.A., Z.M., A.M.M., D.M.F., M.A. and S.A.; writingoriginal draft preparation, A.H.K., Z.u.R., W.A., Z.M., A.M.M., D.M.F., M.A. and S.A.; writing—review and editing, A.H.K., Z.u.R., W.A., Z.M., A.M.M., D.M.F., M.A. and S.A.; visualization, A.H.K. and Z.u.R.; supervision, A.H.K., Z.u.R. and W.A.; project administration, A.H.K. and Z.u.R. All authors have read and agreed to the published version of the manuscript.
\end{abstract}

Funding: This research received no external funding.

Institutional Review Board Statement: Not applicable.

Informed Consent Statement: Not applicable.

Data Availability Statement: Not applicable.

Conflicts of Interest: The authors declare no conflict of interest.

\title{
References
}

1. Zdravkovic, L.; Potts, D.M.; Hight, D.W. The effect of strength anisotropy on the behaviour of embankments on soft clay. Geotechnique 2002, 52, 447-457. [CrossRef]

2. Zhang, J.; Sun, Y.; Cao, J. Experimental Study on the Deformation and Strength Characteristics of Saturated Clay under Cyclic Loading. Adv. Civ. Eng. 2020, 2020, 7456596. [CrossRef]

3. Wu, J.; Xuan, Y.; Deng, Y.; Li, X.; Zha, F.; Zhou, A. Combined vacuum and surcharge preloading method to improve lianyungang soft marine clay for embankment widening project: A case. Geotext. Geomembr. 2020, 49, 452-465. [CrossRef]

4. Chen, Y.; Cai, Y.; Cao, Z. Predicting Postconstruction Settlements Generated by Moving Traffic on Highways Built on Soft Soil in China Using Mechanistic-Empirical Design Method. J. Transp. Eng. Part B Pavements 2019, 145, 05019001. [CrossRef]

5. Marsland, A.; Powell, J.J.M. The Behaviour of a Trial Bank Constructed to Failure on Soft Alluvium of River Thames. In Proceedings of the International Symposium on Soft Clay, Bangkok, Thailand, 5-6 July 1977; pp. 505-525.

6. Tavenas, F.; Mieussens, C.; Bourges, F. Lateral displacements in clay foundations under embankments. Can. Geotech. J. 1979, 16, 532-550. [CrossRef]

7. Fell, R.; MacGregor, P.; Stapleton, D.; Bell, G. Geotechnical Engineering of Embankment Dams; Balkema: Rotterdam, The Netherlands, 1992; p. 675. 
8. Drucker, D.C.; Gibson, R.E.; Henkel, D.J. Soil Mechanics and Work-Hardening Theories of Plasticity. Trans. Am. Soc. Civ. Eng. 1957, 122, 338-346. [CrossRef]

9. Folkes, D.J.; Crooks, J.H.A. Effective stress paths and yielding in soft clays below embankments. Can. Geotech. J. 1985, 22, 357-374. [CrossRef]

10. Graham, J.; Crooks, J.H.A.; Lau, S.L.K. Yield envelopes: Identification and geometric properties. Géotechnique 1988, 38, 125-134. [CrossRef]

11. Mayne, P.W. Profiling yield stresses in clays by in situ tests. Transp. Res. Rec. 1995, 1479, 43-50.

12. Masoud, Z.; Khan, A.H. Prediction of Unloading Failure Strain and Undrained Shear Strength of Saturated Clays by Limit Pressure from Prebored Pressuremeter. Geotech. Test. J. 2021, 44, 1426-1447. [CrossRef]

13. Leroueil, S.; Samson, L.; Bozozuk, M. Laboratory and field determination of preconsolidation pressures at Gloucester. Can. Geotech. J. 1983, 20, 477-490. [CrossRef]

14. Crooks, J.H.A.; Graham, J. Geotcchnical properties of the Belfast estuarine deposits. Geotechnique 1976, 26, 293-315. [CrossRef]

15. Hunter, G.; Fell, R. Prediction of impending failure of embankments on soft ground. Can. Geotech. J. 2003, 40, 209-220. [CrossRef]

16. Huang, M.; Liu, Y.; Sheng, D. Simulation of yielding and stress-strain behaviour of Shanghai soft clay. Comput. Geotech. 2011, 38, 341-353. [CrossRef]

17. Ellithy, G.S.; Stark, T.D. Case Study: Unsaturated Embankment Failure on Soft Soils. J. Geotech. Geoenvironmental Eng. 2020, 146, 05020011. [CrossRef]

18. Zhang, C.-L.; Jiang, G.-L.; Liu, X.-F.; Su, L.-J. Centrifuge Modelling and Analysis of Ground Reaction of High-speed Railway Embankments over Medium Compressibility Ground. KSCE J. Civ. Eng. 2018, 22, 4826-4840. [CrossRef]

19. Jin, S.W.; Choo, Y.W.; Kim, Y.M.; Kim, D.S. Centrifuge modeling of differential settlement and levee stability due to staged construction of enlarged embankment. KSCE J. Civ. Eng. 2014, 18, 1036-1046. [CrossRef]

20. Chen, J.; Liu, J.; Xue, J.; Shi, Z. Failure analyses of a reinforced embankment by Strength Reduction and Limit Equilibrium Methods considering hardening of soft clay. KSCE J. Civ. Eng. 2014, 18, 2043-2050. [CrossRef]

21. Liu, W.; Qu, S.; Zhang, H.; Nie, Z. An integrated method for analyzing load transfer in geosynthetic-reinforced and pile-supported embankment. KSCE J. Civ. Eng. 2016, 21, 687-702. [CrossRef]

22. Liu, P.; Xiong, C.X.; Chen, F.Q. Three-Part Wedge Method for the Stability Calculation of Embankment Supported on Rigid Pile Foundation. KSCE J. Civ. Eng. 2020, 24, 794-806. [CrossRef]

23. Ghorbani, A.; Hosseinpour, I.; Shormage, M. Deformation and stability analysis of embankment over stone column-strengthened soft ground. KSCE J. Civ. Eng. 2021, 25, 404-416. [CrossRef]

24. Jardine, R.J.; Hight, D.W. The Behaviour and Analysis of Embankments on Soft Clay-Special Publication: Embankments on Soft Clays. Bulletin of the Public Works Research Center. 1987, pp. 159-244. Available online: https://trid.trb.org/view/295218 (accessed on 15 December 2021).

25. Ladd, C.C. Stability Evaluation during Staged Construction. J. Geotech. Eng. 1991, 117, 540-615. [CrossRef]

26. Zhang, J.-F.; Chen, J.; Wang, J.-H.; Zhu, Y.-F. Prediction of tunnel displacement induced by adjacent excavation in soft soil. Tunn. Undergr. Space Technol. 2013, 36, 24-33. [CrossRef]

27. Chen, R.; Meng, F.; Li, Z.; Ye, Y.; Ye, J. Investigation of response of metro tunnels due to adjacent large excavation and protective measures in soft soils. Tunn. Undergr. Space Technol. 2016, 58, 224-235. [CrossRef]

28. Guo, P.; Gong, X.; Wang, Y. Displacement and force analyses of braced structure of deep excavation considering unsymmetrical surcharge effect. Comput. Geotech. 2019, 113, 103102. [CrossRef]

29. Yu, F.; Li, S.; Dai, Z.; Li, J.; Chen, S. Stability Control of Staged Filling Construction on Soft Subsoil Using Hyperbolic Settlement Prediction Method: A Case Study of a Tidal Flat in China. Adv. Civ. Eng. 2020, 2020, 8899843. [CrossRef]

30. Guo, P.; Liu, F.; Lei, G.; Li, X.; Zhu, C.-W.; Wang, Y.; Lu, M.; Cheng, K.; Gong, X. Predicting Response of Constructed Tunnel to Adjacent Excavation with Dewatering. Geofluids 2021, 2021, 5548817. [CrossRef]

31. Mitchell, J.K. Practical problems from surprising soil behaviour. J. Geotech. Eng. 1986, 112, 259-289.

32. Costa Filho, L.M.; Werneck, M.L.G.; Collet, H.B. The Undrained Strength of a Very Soft Clay. In Proceedings of the 9th ICSMFE, International Conference on Soil Mechanics and Foundation Engineering, Tokyo, Japan, 10-15 July 1977; Volume 1, pp. 69-72.

33. Magnan, J.P.; Humbert, P.; Mouratidis, A. Finite element analysis of soil deformations with time under an experimental embankment at failure. In Proceedings of the International Symposium on Numerical Models in Geomechanics, Rotterdam, The Netherlands, 13-17 September 1982; pp. 601-609.

34. Blondeau, F.; Queyroi, D.; Peignaud, M.; Mieussens, C.; Levillain, J.P.; Vogien, M. Instrumentation du Remblai Experimental 'A' de Cubzac-Les-Ponts. In Proceedings of the International Symposium on Soft Clay, Bangkok, Thailand, 5-7 July 1977; pp. 419-435.

35. Holtz, R.D.; Holm, G. Test embankment on an organic silty clay. In Proceedings of the 7th European Conference on Soil Mechanics and Foundation Engineering, Brighton, UK, 1 September 1979; pp. 79-86.

36. Wilkes, P.F. An induced failure at a trial embankment at King's Lynn Norfolk, England. In Performance of Earth and Earth-Supported Structures; ASCE: Reston, VA, USA, 1972; pp. 29-63.

37. Wroth, C.P.; Simpson, B. An induced failure at a trial embankment: Part II Finite Element Computations. In Performance of Earth and Earth-Supported Structures; ASCE: Reston, VA, USA, 1972; pp. 65-79. 
38. La Rochelle, P.; Trak, B.; Tavenas, F.; Roy, M. Failure of a Test Embankment on a Sensitive Champlain Clay Deposit. Can. Geotech. J. 1974, 11, 142-164. [CrossRef]

39. Poulos, H.G.; Lee, C.Y.; Small, J.C. Predicted and observed behaviour of a test embankment on Malaysian Soft Clays. Aust. Geomech. 1991, 20, 7-23.

40. Jardine, R.J.; Smith, P.R. Evaluating design parameters for multi-stage construction. In Proceedings of the International Conference on Geotechnical Engineering for Coastal Development, Geo-coast'91, Yokosuka, Japan, 3-6 September 1991 ; pp. $197-202$.

41. Clarke, B.G. Pressuremeters in Geotechnical Design, 1st ed.; CRC Press: London, UK, 1994. [CrossRef]

42. Briaud, J.L. Ménard Lecture: The Pressuremeter Test: Expanding Its Use. In Proceedings of the 18th International Conference on Soil Mechanics and Geotechnical Engineering, Paris, France, 2-6 September 2013.

43. Wroth, C.P. The interpretation of in situ soil tests. Geotechnique 1984, 34, 449-489. [CrossRef]

44. Kulhawy, F.H.; Mayne, P.W. Manual on Estimating Soil Properties for Foundation Design; Electric Power Research Institute: Palo Alto, CA, USA, 1990; p. 306.

45. Avgerinos, V.; Potts, D.M.; Standing, J.R. The use of kinematic hardening models for predicting tunnel-ling-induced ground movements in London Clay. Geotechnique 2016, 66, 106-120. [CrossRef]

46. Windle, D.; Wroth, C.P. The use of a self-boring pressuremeter to determine the undrained properties of clays. Ground Eng. 1977, 10, 37-46.

47. Houlsby, G.T.; Withers, N.J. Analysis of the cone pressuremeter test in clay. Geotechnique 1988, 38, 575-587. [CrossRef]

48. Ferreira, R.S.; Robertson, P.K. Interpretation of undrained self-boring pressuremeter test results incorporating unloading. Can. Geotech. J. 1992, 29, 918-928. [CrossRef]

49. Nutt, N.R.F. Development of the Cone Pressuremeter. Ph.D. Thesis, The University of Oxford, Oxford, UK, 1993.

50. Ferreira, R.; Robertson, P. Large-strain undrained pressuremeter interpretation based on loading and unloading data. Can. Geotech. J. 1994, 31, 71-78. [CrossRef]

51. Rehman, Z.; Akbar, A.; Clarke, B. Characterization of a Cohesive Soil Bed using a Cone Pressuremeter. Soils Found. 2011, 51, 823-833. [CrossRef]

52. Hight, D.W.; Bond, A.J.; Legge, J.D. characterization of the Bothkennaar clay: An overview. Geotechnique 1992, 42, 303-347. [CrossRef]

53. Mun, W.; Teixeira, T.; Balci, M.; Svoboda, J.; McCartney, J. Rate effects on the undrained shear strength of compacted clay. Soils Found. 2016, 56, 719-731. [CrossRef]

54. Głuchowski, A.; Soból, E.; Szymański, A.; Sas, W. Undrained Pore Pressure Development on Cohesive Soil in Triaxial Cyclic Loading. Appl. Sci. 2019, 9, 3821. [CrossRef]

55. Dai, Z.; Guo, J.; Luo, H.; Li, J.; Chen, S. Strength Characteristics and Slope Stability Analysis of Expansive Soil with Filled Fissures. Appl. Sci. 2020, 10, 4616. [CrossRef]

56. Tsuchida, T.; Kitade, K.; Tanaka, M.; Kang, G.-O.; Kaya, K. Evaluation of design shear strength of intermediate soil for construction of breakwater at Port of Sakai. Soils Found. 2020, 60, 239-256. [CrossRef]

57. Leroueil, S.; Kabbaj, M.; Tavenas, F.; Bouchard, R. Stress-strain-strain rate relation for the compressibility of sensitive natural clays. Geotechnique 1985, 35, 159-180. [CrossRef]

58. Lunne, T.; Berre, T.; Andersen, K.H.; Sjursen, M.; Mortensen, N. Effects of sample disturbance on consolidation behaviour of soft marine Norwegian clays. In Proceedings of the 3rd International Conference on Site Characterization, Taipei, Taiwan, 1-4 April 2008; pp. 1471-1479.

59. Jia, R.; Chai, J.-C.; Hino, T.; Hong, Z.-S. Strain-rate effect on consolidation behaviour of Ariake clay. Proc. Inst. Civ. Eng.-Geotech. Eng. 2010, 163, 267-277. [CrossRef]

60. Diaz-Rodriguez, J.A.; Tonix, W.R.; Carrizales, P.M. Constant rate of strain consolidation of Maxico City Soil. In Proceedings of the 19th International Conference on Soil Mechanics and Geotechnical Engineering, Seoul, Korea, 17-22 September 2017.

61. Kauschinger, J.L. Using multi-yield surface model parameters. In Relating Undrained Triaxial and Pressuremeter Stress-Strain Characteristics; ASTM International: West Conshohocken, PA, USA, 1985; pp. 187-213. [CrossRef]

62. Agan, C. Estimating the yield zone boundaries of weak zone of in underground openings by pressuremeter tests: A case study in Canakkale, Turkey. Bull. Eng. Geol. Environ. 2020, 79, 4281-4290. [CrossRef]

63. Graham, J.; Noonan, M.L.; Lew, K.V. Yield states and stress-strain relationships in a natural plastic clay. Can. Geotech. J. 1983, 20, 502-516. [CrossRef]

64. Palmer, A.C.; Rice, J.R. The growth of slip surfaces in the progressive failure of over-consolidated clay. Proc. R. Soc. London. Ser. A Math. Phys. Sci. 1973, 332, 527-548. [CrossRef]

65. Becker, D.E.; Crooks, J.H.A.; Been, K.; Jefferies, M.G. Work as a criterion for determining in situ and yield stresses in clays. Can. Geotech. J. 1987, 24, 549-564. [CrossRef]

66. ASTM D5783-18; Standard Guide for Use of Direct Rotary Drilling with Water-Based Drilling Fluid for Geoenvironmental Exploration and the Installation of Subsurface Water-Quality Monitoring Devices. ASTM International: West Conshohocken, PA, USA, 2018. [CrossRef]

67. ASTM D1587/D1587M-15; Standard Practice for Thin-Walled Tube Sampling of Fine-Grained Soils for Geotechnical Purposes. ASTM International: West Conshohocken, PA, USA, 2016. [CrossRef] 
68. ASTM D4220/D4220M-14; Standard Practices for Preserving and Transporting Soil Samples. ASTM International: West Conshohocken, PA, USA, 2014. [CrossRef]

69. Masoud, Z.; Akbar, A.; Khan, A.H. High quality and cost effective drilling system for prebored pressuremeter testing. Soils Found. 2013, 53, 903-909. [CrossRef]

70. Masoud, Z.; Khan, A.H. An Improved Technique for Prebored Pressuremeter Tests. KSCE J. Civ. Eng. 2019, $23,2839-2846$. [CrossRef]

71. ASTM D5434-12; Standard Guide for Field Logging of Subsurface Explorations of Soil and Rock. ASTM International: West Conshohocken, PA, USA, 2012. [CrossRef]

72. ASTM D4719-20; Standard Test Methods for Prebored Pressuremeter Testing in Soils. ASTM International: West Conshohocken, PA, USA, 2020. [CrossRef]

73. ASTM D1452/D1452M-16; Standard Practice for Soil Exploration and Sampling by Auger Borings. ASTM International: West Conshohocken, PA, USA, 2016. [CrossRef]

74. Li, A.L.; Rowe, R.K. Some Design Considerations for Embankments on Rate Sensitive Soils. J. Geotech. Geoenvironmental Eng. 2002, 128, 885-897. [CrossRef]

75. ASTM D6913/D6913M-17; Standard Test Methods for Particle-Size Distribution (Gradation) of Soils Using Sieve Analysis. ASTM International: West Conshohocken, PA, USA, 2017. [CrossRef]

76. ASTM D7263-09(2018)e2; Standard Test Methods for Laboratory Determination of Density (Unit Weight) of Soil Specimens. ASTM International: West Conshohocken, PA, USA, 2018. [CrossRef]

77. ASTM D4318-17e1; Standard Test Methods for Liquid Limit, Plastic Limit, and Plasticity Index of Soils. ASTM International: West Conshohocken, PA, USA, 2018. [CrossRef]

78. ASTM D2216; Test Methods for Laboratory Determination of Water (Moisture) Content of Soil and Rock by Mass. ASTM International: West Conshohocken, PA, USA, 2019. [CrossRef]

79. ASTM D2487; Standard Practice for Classification of Soils for Engineering Purposes (Unified Soil Classification System). ASTM International: West Conshohocken, PA, USA, 2017. [CrossRef]

80. ASTM D854-14; Standard Test Methods for Specific Gravity of Soil Solids by Water Pycnometer. ASTM International: West Conshohocken, PA, USA, 2014.

81. ASTM D4767-11; Standard Test Method for Consolidated Undrained Triaxial Compression Test for Cohesive Soils. ASTM International: West Conshohocken, PA, USA, 2020.

82. ASTM D-4186/D-4186M-12e1; Standard Test Method for One-Dimensional Consolidation Properties of Saturated Cohesive Soils Using Controlled-Strain Loading. ASTM International: West Conshohocken, PA, USA, 2012. [CrossRef]

83. Graham, J.; Pinkney, R.B.; Lew, K.V.; Trainor, P.G.S. Curve-fitting and laboratory data. Can. Geotech. J. 1982, 19, 201-205. [CrossRef]

84. Wrzesiński, G.; Sulewska, M.J.; Lechowicz, Z. Evaluation of the Change in Undrained Shear Strength in Cohesive Soils due to Principal Stress Rotation Using an Artificial Neural Network. Appl. Sci. 2018, 8, 781. [CrossRef]

85. Silva, I.N.; Indraratna, B.; Nguyen, T.T.; Rujikiatkamjorn, C. Shear behaviour of subgrade soil with reference to varying initial shear stress and plasticity index. Acta Geotechnica 2022, 2, 1-10. [CrossRef]

86. Yin, J.; Zhang, K.; Geng, W.; Gaamom, A.; Xiao, J. Effect of initial water content on undrained shear strength of Ko consolidated clay. Soils Found. 2021, 61, 1453-1463. [CrossRef]

87. Bowles, J.E. Foundation Design and Analysis; MacGraw Hill: New York, NY, USA, 1982.

88. Nguyen, T.T.; Indraratna, B. Rail track degradation under mud pumping evaluated through site and laboratory investigations. Int. J. Rail Transp. 2022, 10, 44-71. [CrossRef]

89. Won, J.; Park, J.; Kim, J.; Jang, J. Impact of Particle Sizes, Mineralogy and Pore Fluid Chemistry on the Plasticity of Clayey Soils. Sustainability 2021, 13, 11741. [CrossRef]

90. Jakšić, S.; Ninkov, J.; Milić, S.; Vasin, J.; Živanov, M.; Jakšić, D.; Komlen, V. Influence of Slope Gradient and Aspect on Soil Organic Carbon Content in the Region of Niš, Serbia. Sustainability 2021, 13, 8332. [CrossRef]

91. Lahuta, H.; Pais, L. Research of the Behavior of Clay Materials with Double Porosity. Sustainability 2021, 13, 3219. [CrossRef] 